\title{
Is There a Trend towards Global Value Chain Specialization? An Examination of Cross Border Sales of US Foreign Affiliates
}

\author{
Beugelsdijk, Sjoerd; Pedersen, Torben; Petersen, Bent
}

Document Version

Final published version

Publication date:

2008

License

CC BY-NC-ND

Citation for published version (APA):

Beugelsdijk, S., Pedersen, T., \& Petersen, B. (2008). Is There a Trend towards Global Value Chain Specialization? An Examination of Cross Border Sales of US Foreign Affiliates. Center for Strategic Management and Globalization. SMG Working Paper No. 24/2008

Link to publication in CBS Research Portal

\section{General rights}

Copyright and moral rights for the publications made accessible in the public portal are retained by the authors and/or other copyright owners and it is a condition of accessing publications that users recognise and abide by the legal requirements associated with these rights.

Take down policy

If you believe that this document breaches copyright please contact us (research.lib@cbs.dk) providing details, and we will remove access to the work immediately and investigate your claim. 
IS THERE A TREND TOWARDS GLOBAL VALUE CHAIN SPECIALIZATION? - AN EXAMINATION OF CROSS BORDER SALES OF US FOREIGN AFFILIATES

\author{
Sjoerd Beugelsdijk \\ Torben Pedersen \\ Bent Petersen
}

SMG WP 24/2008

July 29, 2008 
SMG Working Paper No. 24/2008

July 29, 2008

ISBN: 978-87-91815-37-9

Center for Strategic Management and Globalization Copenhagen Business School

Porcelænshaven 24

2000 Frederiksberg

Denmark

www.cbs.dk/smg 
IS THERE A TREND TOWARDS GLOBAL VALUE CHAIN SPECIALIZATION?

- AN EXAMINATION OF CROSS BORDER SALES OF US FOREIGN AFFILIATES

\author{
SJOERD BEUGELSDIJK \\ Department of Economics \\ Nijmegen School of Management \\ PO Box 9108 \\ 5000 HK Nijmegen \\ The Netherlands \\ e-mail: s.beugelsdijk@fm.ru.nl \\ phone: +31 (0)243615886 \\ fax: +31 (0)24361 2379 \\ TORBEN PEDERSEN \\ Center for Strategic Management and Globalization \\ Copenhagen Business School \\ Denmark \\ e-mail: tp.smg@cbs.dk \\ phone: +4538152522 \\ fax: +45 38153035 \\ BENT PETERSEN \\ Center for Strategic Management and Globalization \\ Copenhagen Business School \\ Denmark \\ e-mail: bp.smg@cbs.dk \\ phone: +4538152510 \\ fax: +45 38153035
}




\begin{abstract}
In this study we discuss and empirically test the assertion that over the last two decades multinational enterprises' (MNEs') configuration of value-adding activities has shifted from a sparse and simple (host-home) international division of labor among the foreign affiliates to a more specialized and 'advanced' global value chain configuration in which MNEs locate finesliced parts of the value chain at the most efficient locations. Using data on trade flows of U.S. affiliates in 56 host countries between 1983 and 2003 we find some indications of a trend in the direction of global value chain specialization. In particular among US affiliates in developing countries the proportion of host-host, intra-firm trade has increased significantly during the observed period of time. Conversely, the proportion of host-home and inter-firm trade has diminished. We interpret this as indicating both value chain disaggregation (vertical specialization) and MNEs' systematic exploitation of factor cost differentials across countries. We also find that the absolute levels of all types of trade flows have increased. Hence, it is the relative, and not the absolute, changes in the trade flow patterns of US affiliates that gives credibility to the global value chain assertion.
\end{abstract}

Keywords: FDI, US affiliate sales, globalization, value chain specialization 
IS THERE A TREND TOWARDS GLOBAL VALUE CHAIN SPECIALIZATION? - AN EXAMINATION OF CROSS BORDER SALES OF US FOREIGN AFFILIATES

\section{Introduction}

It is the general contention that the removal of trade and investment barriers around the world, as well as falling transport and communication costs have triggered a change of the global FDIpattern in the direction of a more pronounced and sophisticated division of labor within the multinational enterprise (MNE) (Zaheer and Manrakhan, 2001; Dicken, 2003; Kotabe and Murray, 2004). MNEs are seen as shifting from dispersed to concentrated global value chain (GVC) configurations (Porter, 1986), meaning that the various value chain activities of the corporation, instead of being replicated from country to country (and therefore 'dispersed'), are being concentrated and specialized in one or a few locations where the factor endowment is the most favorable. Hence, MNEs develop into 'differentiated networks' (Nohria and Ghoshal, 1994) or 'meta-nationality' (Doz et al., 2001) characterized by an outspoken international division of labor and resulting strong interdependency between the affiliations. International management scholars have translated this phenomenon into a surge for 'global integration', ‘transnational strategies’ (Prahalad and Doz, 1987; Bartlett and Ghoshal, 1989; Yip, 1989), and economic geographers have used terms like 'global production networks' and 'global commodity chains' to describe the new division of labor incorporated or 'governed' by the MNE (Gereffi, 1999; Schmitz, 2003; Humphrey, 2005). In the business press the attention has foremost been on the relocation - offshoring - of value chain activities from the MNE home countries in the developed market economies to low cost developing countries, such as Mexico, China and India. Not surprisingly, offshoring is also prominent on the agenda of policymakers given its impact on 
and relationship with national labor markets, national competitiveness, and terms of trade (e.g. Economic Policy Institute, 2005; Smyth, 2006; Farrell 2005 versus Levy 2005).

There is amble evidence (see e.g. Lewin and Peeters, 2006) that offshoring has grown significantly over the last ten years. Not only has 'traditional' offshoring of manufacturing activities increased, but new forms of offshoring, of services ('white collar jobs', 'back office activities') and R\&D, have emerged (Nachum and Zaheer, 2005; Ramamurti, 2004; Grossman and Helpman, 2005; Antras et al. 2006; Yeaple, 2006) - often referred to as the second and third wave of offshoring, respectively (McKinsey Global Institute, 2007; Farell, 2004, 2006; Engardio et al. 2003).

However, it is important to note that the offshoring phenomenon as such, implies a relocation of value chain activities - a 'functional migration' - from MNE home countries to foreign countries - but not necessarily a more concentrated or specialized GVC. There is amble anecdotal evidence of GVC specialization making up a natural part of the offshoring process (see e.g. Robinson and Kalakota, 2004) - notably through the establishment of shared services centers within the multinational corporation - but to our knowledge no large-scale studies have been carried out which can confirm or deny a juxtaposition of offshoring and GVC specialization.

Hence, the assertion - or 'thesis' - that the MNEs in general are moving towards GVC specialization does not seem to rest on solid empirical basis - if any at all. It is thus the aim of this study to examine the GVC specialization 'thesis' empirically. We do that on a comprehensive data set on trade flows of US foreign affiliates during a period of twenty years (1983-2003). By using this new database we establish fine-grained measures of different types of cross border sales that result as a consequence of non-market seeking FDI of US MNEs. 
Our contribution is twofold. First, by fine-slicing the broad notion of GVC configuration in different constitutive components we provide a more intricate picture of the supposed trend towards global value chains of MNEs. Second, we show that the share of total cross border affiliate sales (relative to local sales) has not really increased over the last two decades. In other words, vertical disintegration of MNE global value chains has not significantly changed the overall balance between cross border sales and local sales of MNE affiliates. However, if we look isolated at the cross border sales pattern of US affiliates some changes do emerge - in terms of the balance between inter- and intra-affiliate sales as well as in relation to host-home versus host-host sales. The most significant single change of the cross border affiliate trade pattern appears to be the growth of host-host intra-firm sales - but only from affiliates in developing countries, not in developed countries.

By investigating the underlying structure of cross border sales, we also follow up on Buckley and Ghauri (2004: 81) who argued that the analysis of the changing configuration strategy of MNEs and its impact on the world economy is one of the big questions in international business. Our study has implications for the broader globalization debate by providing new arguments based on empirical material - something we consider highly needed for a balanced discussion of the pros and cons of globalization.

The balance of the article is organized as follows: In the next section (section 2) we make a further account for the global value chain concept and its theoretical basis. Our interpretations and categorizations of different affiliate trade flows lead to the formulation of a set of hypotheses revolving around a test of the GVC specialization thesis. In section 3 we measure and describe cross border sales of US foreign affiliates. In section 4 the hypotheses pertaining to the asserted 
reconfiguration of value-adding activities of MNEs - the GVC specialization thesis - are tested, and subsequently we interpret and discuss the results. Section 5 concludes.

\section{Theory and hypotheses}

In order to properly understand the notion of GVC and its empirical counterpart, cross border sales, it is important to sketch the different types of sales that occur as a result of MNE activity, most notably local sales and cross border sales. The distinction between local sales and cross border sales to a large extent mirrors the conventional, basic theoretical distinction between horizontal and vertical FDI. Horizontal FDI accumulates local sales, vertical FDI cross border sales. Horizontal FDI arises as a substitute for exporting and a desire to place production close to customers and thereby avoid trade costs, being both transportation costs and trade barriers (Buckley and Casson, 1981). An alternative designation of this type of FDI is market-seeking FDI. Most of the discussion on globalization, and definitely the debate on GVC specialization, refer to the non-market seeking type of FDI. Vertical FDI is traditionally related to the desire of MNEs to exploit factor cost differentials in locations that are relatively abundant with different factors of production (Braconier et al. 2005; Markusen, 1995). The term vertical FDI is used loosely referring to: (i) resource exploiting MNE activities in a foreign country to serve the home market in a more efficient way; (ii) the concentration of production activities abroad which are subsequently shipped back to the parent in the home country (intra-firm exports); and (iii) the splitting up of the value chain in multiple countries increasing the intra-firm exports between affiliates located in several host countries. The overall characteristic of all these types of FDI is 
that they are initiated out of (anticipated) factor cost differentials and are non-market seeking. ${ }^{1}$ Evidently, the exploitation of factor cost differentials by MNEs implies cross border sales; otherwise the affiliate would only compete with local firms having access to the same (beneficial) factor conditions. So, GVC specialization is associated with cross border sales - not local sales.

However, there are no signs of a fundamental change in the balance between local and cross border affiliate sales, see Table 1 . The table shows accumulated local sales and cross border sales of US foreign affiliates during the period 1983-2003. Absolute t-values of equality of means test first five years = last five years indicate that cross border sales have not increased significantly in relation to local sales. As can be seen in Table 1, the proportion of cross border US affiliate sales is constantly approximately $1 / 3$ of total sales during the observed period of time, with minor differences between developed and developing countries. These figures correspond with results reported by others (e.g. Brainard, 1997).

$<$ Insert Table 1 about here $>$

Because global specialization allows MNEs to arbitrage factor cost differences between countries, Deardorff (1979) described a 'chain of comparative advantage' wherein countries

\footnotetext{
${ }^{1}$ Acknowledging that the early works on non-market seeking FDI generally focused on unskilled labor intensive activities, increasingly MNEs seek knowledge-intensive resources abroad. This shift from unskilled to skilled labor has also led to new terminology in an attempt to capture this phenomenon, e.g. knowledge seeking FDI (Nachum and Zaheer, 1995). Strictly speaking the underlying rationale for both unskilled and skilled labor has not changed however. In both cases, MNEs arise to take advantage of international factor-cost differences and geographically split up their production process (Carr et al., 2001). Incorporating future factor cost differentials that arise as a consequence of relative factor endowments, MNEs are not only interested in relatively unskilled labor but also highly-skilled white collar workers that are becoming increasingly scarce in their home countries.
} 
specialize in different intermediate products according to factor cost differences. Kogut (1985) extended this analysis to the level of the firm, suggesting that MNEs should locate different value chain activities according to their relative use of factor inputs. Yet countries differ not only in terms of factor costs, but also in terms of the "availability of particular skills" (Yip, 1989: 37) and more generally in terms of "the quality, quantity and configuration of its material, human and institutional resources, including 'soft' resources such as inter-organizational linkages, the nature of its educational system, and organizational and managerial know-how” (Westney, 1985, cited by Ghoshal, 1987: 433). Hence the potential for comparative advantage-based specialization seems to be much larger than a simple factor cost view would suggest: in principle, assuming zero coordination or transportation costs, each value chain activity, or even each task, could be optimally located in a different country to extract unique local resources.

In cases where MNEs are localising value chain activities across country borders, one may speak of global value chain configurations (Porter, 1986). Porter (1986) distinguishes between dispersed and concentrated global value chain configurations. In the former, a company locates each value chain activity in a scattered manner, where value chain activities are replicated from country to country. In some countries, only a few activities, such as marketing and sales, are carried out, whereas the corporation may replicate the full range of activities of the value chain in others, thereby forming 'mini-replica'. In contrast, firms may configure their value chain in such a way that the individual activity is carried out at a few locations or at only one. In the extreme case, all of a firm's value chain activities are exercised in different countries, taking full advantage of factor endowment differentials. The local subsidiary is the sole performer of specific activities in the firm's value chain and, as such, the subsidiary is assigned a corporate 
world mandate (Frost et al., 2000; Holm and Pedersen, 2000). In other words, an international division of labor takes place within the corporation's value chain.

We can infer from the above that global value chain specialization has two dimensions: an organizational and a geographical. The organizational dimension pertains to the disaggregation (or 'fine-slicing') and modularization of the value chain into independent units with a sought minimum of mutual interfaces (Sanchez and Mahoney, 1996). The typical sequence of the MNE is that multiple, replicated value chain activities are consolidated into one or a few geographically centralized units (e.g. shared services centers in finance and accounting). In turn, the horizontal consolidation of the various value-adding activities within the corporation allows for a more fine-sliced vertical disaggregation of activities. Subsequently, the individual value-adding activity is located where factor costs are most beneficial for the exercise of that particular activity.

Porter's global value chain configuration framework (Porter, 1986) reflects this dichotomy very nicely in so far as the optimal value chain configuration of the MNE is described as a tradeoff between benefits of locating value-adding activities according to factor endowment and costs of coordination in terms of flows of information and people. A re-configuration of the MNE value chain in the direction of a more advanced international division of labor within the corporation will have substantial implications for the trade flows - sales - of the foreign affiliates and the parent. If such a GVC specialization is indeed a correct description of reality, we can identify at least two ways - capturing both the organizational and the geographical dimension - in which cross border affiliate sales flows potentially are affected: (1) A changing balance between inter- and intra-firm affiliate sales; (2) A changing balance between host-home and host-host sales. 
In the following we will discuss - one by one - how we translate the effects of GVC specialization into these two main types of affiliate sales flows.

\subsection{Inter-firm versus intra-firm affiliate sales}

As a first implication of increased GVC specialization we would expect more intra-firm cross border affiliate sales - relative to inter-firm cross border sales. This has to do with the previously mentioned disaggregation of the MNE value chain. All else being equal, the more division of labor between the MNE affiliates the more intra-firm sales. Conversely, the local sales oriented mini-replica MNE affiliation comprises all or most value-adding activities and sells basically finished goods and services to local, independent firms. A dispersed GVC configuration (Porter, 1986) would consist of multiple, horizontal FDIs ('miniature replica') operating at relatively low scales. The sacrifice of scale economies also has the implication that the value-adding activities of the affiliate to a large extent share inputs and the establishment of an internal price market is therefore unlikely simply because the activities are not technological separable (Williamson, 1985), or expressed differently, the interface between various value-adding activities is substantial. Formally,

$\mathrm{H}_{1}$ : Cross border intra-firm sales of foreign affiliates have increased significantly more than cross border inter-firm sales.

\subsection{Host-home versus host-host affiliate sales}

As a second main effect of GVC specialization we would expect an increase of host-host sales relative to host-home. As we discussed above, the literatures in development economics and 
international business provide strong theoretical arguments as to why one would expect a relative increase of value chain specialization spanning multiple countries and a relative decrease of affiliate sales between one home and one host country. Over the past twenty years we have observed a geographical, or spatial, dimension where the trend is that MNEs are moving away from a clear center-periphery (home-host) division of labor and towards a multi-center (differentiated) localization structure with a more sophisticated specialization. In our context the globalization trend infers less home-host (or rather, host-home) affiliate sales flows and more host-host sales. The interpretation is that non-home subsidiaries are moving up the value chain at the expense of the parent - simply because the MNEs to an increasing extent exercise a 'mostefficient-location' strategy. Hence,

$\mathrm{H}_{2 \mathrm{a}}$ : Cross border host-host intra-firm sales of foreign affiliates have increased significantly more than cross border host-home intra-firm sales.

The splitting-up of the MNE value chain and the subsequent (re)location decisions accelerated during the 1980es and - in particular - the 1990es (see e.g. Dicken, 2003). The time period coincides with the opening of many (developing) economies, such as the Chinese and Indian. To MNEs these emerging markets represented a new, attractive 'package' of factor endowments that appeared as obvious, new location for manufacturing as well as service activities. These emerging markets would, to a large extent, challenge the MNE home country as the natural host for 'centers of excellence' and 'world mandate' production hubs. In the pursuit of factor cost differentials more and more affiliates in developing countries will assume status as division of labor hubs and, 
consequently, more trade flows will be between affiliates outside the MNE home country. Hence, we expect the process of GVC to be especially strong for developing countries. Formally,

$\mathrm{H}_{2 \mathrm{~b}}$ : Cross border host-host intra-firm sales of foreign affiliates in developing countries have increased significantly more than cross border host-home intra-firm sales.

Figure 1 indicates the hypothesized change in affiliate trade patterns as a result of GVC specialization.

$<$ Insert Figure 1 about here $>$

\section{Measuring and describing cross border sales of US foreign affiliates}

Data and sample

We test our hypotheses using data on aggregate U.S. foreign affiliate sales to affiliated and unaffiliated parties in a large sample of host countries between 1983 and 2003. We obtained these aggregate affiliate sales data from the database US Direct Investment Abroad: Financial and Operating Data of the U.S. Bureau of Economic Analysis (BEA). For majority-owned nonbank affiliates of non-bank U.S. parents, these data are broken down into sales to unaffiliated parties located in the focal host country, the U.S., and third countries, and into sales to affiliated parties located in these three categories of countries. We use this detailed subdivision of affiliate sales to distinguish between different types of foreign value-adding activities.

We focus on the foreign sales of U.S. manufacturing firms for several reasons. First, U.S. foreign affiliate sales are the highest in the world (Brainard, 1997; WTO, 2005). Second, to the 
best of our knowledge, the U.S. is the only country for which detailed data on the aggregate sales of its foreign affiliates is available on a yearly basis. And finally, the fact that we have data on U.S. multinationals fits the fact that the offshoring debate on non-market seeking FDI has especially been prominent on the agenda of policymakers and academics in the United States.

Our sample is not balanced in the sense that for some countries and years certain types of sales are not known or not reported for reasons of confidentiality. The number of host countries included in our analyses is 56, but for most countries not all 21 years are covered. Obviously the numbers reported below are host- and home-country specific. They are home-country specific, because the U.S. is a large economy with a large home market, which differs from countries like the Netherlands or Denmark which are small open economies. As a consequence the relative shares of market seeking and (types of) non-market seeking FDI will differ accordingly. The data reported below are also host-country specific, because it is a number of host-country characteristics that is associated with certain types of FDI.

\section{Describing the pattern of affiliate cross border sales}

Figure 2 show the different affiliate cross border sales flows for which we have data. The flows can be organized along two key dimensions; host-home versus host-host, and intra-firm versus inter-firm.

$<$ Insert Figure 2 about here $>$

Based on the classification of affiliate sales flows in Figure 2, we have calculated the shares of these types in total cross border sales for the period 1983-2003. In calculating these shares, we have excluded the flow from subsidiary A to subsidiary B within the same host 
country because it is unknown where the goods go to after value has been added in subsidiary B. This could both be back to the U.S. or to a third country, and to affiliated parties or unaffiliated parties, which makes classification impossible. Including this type of affiliate sales in total cross border sales when calculating the different shares does not affect our results and conclusion (results not shown but available upon request). The resulting shares are shown in Table 2a-2c. Because we expect that the amount of affiliate cross border sales has especially increased in countries with relatively cheap (labor) inputs, we distinguish between trade flows from affiliates in developed and developing countries.

$<$ Insert Table 2a about here $>$

Table 2a shows the yearly shares of the different cross border sales types for the full sample $(N=652)$. Table $2 \mathrm{~b}$ and $2 \mathrm{c}$ do the same for developing host countries $(\mathrm{N}=270)$, respectively developed host countries $(\mathrm{N}=382)$. The dichotomous distinction between developed and developing is based on the value of GDP per capita in these countries, being either below the sample mean, or above the sample mean (which is 11,785 current U.S. dollars, PPP corrected). Of total cross border sales, about $28 \%$ is host-home sales and $72 \%$ concerns sales that go from one host country to another host country (time-averaged scores). The majority of the host-home sales concern intra-firm sales (24\%) and only $4 \%$ is being transported back from the host to unaffiliated customers in the United States. The cross border sales that concern multiple host countries are almost equally distributed between intra- and inter-firm sales: The share of hosthost inter-firm sales is $34 \%$ and the share of its intra-firm equivalent is $38 \%$. Not taking the country characteristics into account, we have tested for each type of cross border sales (and their 
respective sums) if the average score in the first five years (1983-1988) differs significantly from the average score in the last five years (1999-2003).

In line with our theoretical expectation (hypothesis 1), the affiliate trade flow structure has changed in the direction of a higher share of intra-firm sales relative to inter-firm. The descriptive data in Table 2a show that total intra-firm sales have increased from $59.8 \%$ between $1983-1988$ to $63.4 \%$ in the $1999-2003$ period $(|t|=1.96, \mathrm{p}<.05)$.

Furthermore, and without discussing all countries in detail ${ }^{2}$, hypotheses $2 \mathrm{a}$ and $2 \mathrm{~b}$ predict a change over time in the types of cross border sales from 'simple' host-home sales to those investments associated with the process of GVC specialization, i.e. host-host, and specifically its intra-firm component. The descriptive data in Table 2a tell us that the structure of cross border sales has indeed changed over time, with a decrease from host-home sales from $29.4 \%$ in the 5year period $1983-1988$ to $26.3 \%$ in the 5 -year period $1999-2003$. In line with our theoretical

\footnotetext{
${ }^{2}$ Underneath these general characteristics, substantial country-level deviations exist. For example, for Mexico as a country close to the United States and with relatively low wages compared to the U.S., we may expect that especially the share of host-home sales will be relatively high. This may be for both intra-firm (from subsidiary to parent) and arm's length (from Mexico direct sales to U.S. customers) sales. The data show that especially the intrafirm host-home sales are the bulk of the total U.S. affiliate sales in Mexico. The time-averaged share is $71 \%$ which is far above the average of host-home sales, followed by host-host intra-firm sales (11\%), and inter firm sales (both host-home and host-host 4\%). Canada, which is much closer to the United States in terms of consumer preferences and level of economic development, is also dominated by host-home sales. As expected, the share of sales directly aimed at U.S. customers is far above average, i.e. $14 \%$ host-home inter-firm versus the overall average of $4 \%$ for all countries. Nevertheless, the bulk of the U.S. affiliate sales in Canada is intra-firm (71\%), i.e. from Canada back to U.S. parents. The Netherlands, a country with a high level of economic development, approximately equal production costs compared to the U.S. (at least higher than Mexico), but located at a large distance from the U.S. has a correspondingly low share of host-home sales. Both types of host-home sales are far below average with $4 \%$ going from the Netherlands back to U.S. MNEs and $0.9 \%$ to the U.S. customers. However, given its central location in Europe and the barriers to export from the U.S. to European countries because of EU trade barriers, its share of hosthost inter-firm sales is about 10 percentage points higher than the average of 34\% (export platform). The same holds for host-host intra-firm sales (global sourcing).
} 
expectation, host-host intra-firm sales have increased (from 34.4\% between 1983-1988 to 41\% in the 1999-2003 period). Just like the cross-sectional scores, individual country scores may be more or less pronounced. For example, Mexico has increased its share of host-home inter-firm sales from below average to above average after joining NAFTA (effective January 1994). On the other hand, intra-firm host-home sales (i.e. sales from affiliates in Mexico to the US parent) have decreased after NAFTA. This is probably because NAFTA allows U.S. MNEs to serve the U.S. home market directly instead of using intra-firm transactions.

Unpaired t-tests between the shares in the first and the last period indicate that significant differences exist for the share of host-host sales in the total sample, both for inter firm host-host $(|\mathrm{t}|=1.876, \mathrm{p}<.10)$ and intra-firm host-host $(|\mathrm{t}|=2.969, \mathrm{p}<.01)$. Only the latter result is robust for excluding 1983 observations. In this case we find that the share of intra-firm host-host sales is significantly higher in the latter period than in the first period, which is in line with hypothesis 2a.

$<$ Insert Table 2b and 2c about here $>$

Table 2b and Table 2c show the scores of the different shares between 1983 and 2003 for the set of developing and developed countries. Distinguishing between developing (Table 2b) and developed countries (Table 2c) show differences between the first and the last period are especially significant in developing countries: host-home sales are significantly lower in the 1999-2003 period than in the period 1983-1988 in developing countries $(|t|=1.784, \mathrm{p}<.10)$. In line with hypothesis $2 \mathrm{~b}$ for affiliate sales from developing countries we find that the host-home intra-firm sales that has decreased $(|\mathrm{t}|=1.79, \mathrm{p}<.10)$ while the host-host intra-firm sales has increased significantly in the latter period $(|t|=2.969, \mathrm{p}<.01)$. These differences are even more 
pronounced when 1983 is excluded. For the set of developed countries we find no such pattern when comparing the 1983-1988 period with the 1999-2003 period. Other than an apparent increase in total intra-firm sales $(|t|=2.15, \mathrm{p}<.05)$, supporting hypothesis 1 , we obtain no robust significant differences when comparing the two periods of observation. This finding is however not reflected in significant differences on the scores of the two components (host-home and hosthost), suggesting this result is not robust.

These descriptive statistics largely support our hypotheses 1 , 2a and $2 b$, but to formally test if significant shifts in the pattern of cross border sales can be observed we relate the three different shares (and their respective sums) to a time-trend variable while controlling for a broad range of host country characteristics.

\section{Testing the changing pattern of cross border sales}

The set up of our regression equation is derived from traditional gravity equations in international economics (e.g., Tinbergen, 1962; Linnemann, 1966; Geraci and Prewo, 1977; Leamer and Levinsohn, 1995; Anderson and Marcouiller, 2002; Rose, 2004; Huang, 2007). Such models have been shown to have clear theoretical foundations (Anderson, 1979; Bergstrand, 1985) and have produced some of the clearest and most robust empirical results in international economics (Leamer and Levinsohn, 1995; for an overview, see Frankel, 1997). They postulate that merchandise trade flows between countries depend on several characteristics of these countries (Bergstrand, 1985; Brainard, 1997). These factors include transportation costs, typically proxied by the presence or absence of a shared land border and by geographic distance, and formal trade barriers, often proxied by the presence or absence of free trade agreements. Although originally used to explain export flows, gravity models have also been used 
successfully to explain FDI flows, foreign affiliate sales, and the share of exports and affiliate sales in total foreign sales (Brainard, 1997; Habib and Zurawicki, 2002; Braconier et al., 2005; Cuervo-Cazurra, 2006).

\section{Dependent variables}

We use the four dependent variables reflecting the different cross border sales flows as distinguished in Figure 2. In addition to these four, we also include the sum of intra- and inter firm host-home sales (total host-home) and the sum of intra-firm home host and intra-firm hosthost (total intra-firm). All these sales flows are calculated in terms of their share in total cross border sales. In sum:

i) Total of host-home sales. Given the fact that total of host-home is equal to $100 \%$ minus the total of host-host, the results for host-host are mirrored in the host-home results. Coefficients are the same, but signs are opposite.

ii) Total of intra-firm sales. For reasons explained above, the results for the total interfirm sales are opposite to the results for total intra-firm sales.

iii) Host-home intra-firm sales;

iv) Host-home inter-firm sales;

v) Host-host inter-firm sales;

vi) Host-host intra-firm sales;

If our thesis on a trend towards a GVC specialization is correct, we would observe a significant decrease of the host-home sales (especially the intra-firm host-home) compared to the intra-firm host-host sales over time (Hypothesis 2a and 2b). We complement our set of dependent variables with data on our independent variables, resulting in a panel of 56 countries and 21 years (see 
Appendix A for a list of these countries). Due to missing observations for some years, our final dataset consists of 652 observations. Because we control for first order autocorrelation (AR1), and heteroskedasticity our regressions are based on a feasible generalized least squares (GLS) method.

\section{Independent variables}

Time trend: To capture the changing pattern over time, we include a time-trend measuring the number of years since $t=1983$. We expect a negative coefficient for the time trend variable when explaining host-home sales (hence a positive for host-host) and we hypothesized a positive coefficient for the variable measuring intra-firm cross border sales.

Level of economic development: We include the log of Gross Domestic Product (GDP) per capita to control for differences in level of economic development. GDP per capita is measured in current U.S. dollars and corrected for purchasing power parities. These data are taken from the World Development Indicators.

Time trend $x$ GDP per capita interaction: We include an interaction effect between the timetrend and GDP per capita for two reasons; (i) because we are looking at cross border sales and it is especially local sales (market seeking FDI) that goes to developed countries and cross border sales (non-market seeking) that goes to developing countries, we expect that the time trend differs for developed and developing countries and we control for this by this interaction effect. The presence of such an effect is also reflected in the different results in developed and developing countries of the t-tests as discussed earlier; (ii) related to the previous empirical argument, we theorized that the process of global value chain specialization especially occurs in developing countries and not in developed countries. The interaction effect is included to 
explicitly test this moderating effect of level of economic development as formally hypothesized in hypothesis $1 \mathrm{~b}$ and $2 \mathrm{~b}$. We expect to find a negative interaction effect in the regression explaining intra-firm cross border sales (Hypothesis 1b) and a positive interaction effect in the regression explaining the share of host-home sales (hypothesis 2b). In addition to the above variables we control for a number of other host country characteristics typically included in gravity type models.

\section{Control variables}

Geographic distance: As is commonly done in gravity equations, we control for geographic distance between the U.S. and each host country by including the log of the great-circle geographic distance (in kilometers) between our 56 country pairs (e.g. Grosse and Trevino, 1996; Bevan et al., 2004; Cuervo-Cazurra, 2006). Data were obtained from the distance calculator of the U.S. Department of Agriculture. Geographic distance is expected to have a negative effect on the share of host-home sales, since increasing geographic distance is associated with higher transportation costs making it less attractive to produce abroad and export back to the U.S. (Frankel, 1997). For a similar reason we expect a positive effect of geographic distance on the share of host-host intra-firm sales, because with a low geographic distance between the U.S. and host country A, the question arises why one would not directly serve the subsidiary in host country B from the U.S. instead of through host country A (ceteris paribus). In other words, we associate an increase in host-host intra firm sales with increasing levels of geographic distance.

Shared border: As is commonly done in international economics (Leamer and Levinsohn, 1995; Frankel, 1997), we include a dummy coded 1 if the host country has a shared border with the U.S. Note that this shared border variable also measures NAFTA membership (or its predecessor 
CUSFTA), because Canada is NAFTA member as of 1989 and Mexico as of 1994 . We expect a positive relationship between the shared border dummy and the share of host-home sales because of the low transportation costs. For reasons explained above, we expect a negative relationship between shared border dummy and the host-host intra-firm sales.

Openness: Following Kumar (1994) and Habib and Zurawicki (2002), among others, we control for the openness of each host country through the sum of its worldwide merchandise imports and exports as a percentage of its GDP. This percentage was obtained from the World Development Indicators (WDI). We expect a positive relationship between openness and our dependent variables as all cross border sales types entail exports, either from the host country to the U.S. or from a host country to a third country.

GATT/WTO: We include a 0-1 dummy variable indicating whether a specific host country was a member of the World Trade Organization (or its predecessor, GATT) in a given year. We expect a positive effect of GATT/WTO membership for all our dependent variables.

Fixed effects: Finally, we control for both country- and year-specific effects by including country dummies (default is Mexico) and year dummies (default is 1983). The country dummies measure all omitted country level factors (e.g. institutional and cultural factors) not accounted for by the independent variables, and the year dummies measure the year specific deviation from the time-trend.

\section{Results}

The correlation matrix displayed in Table 3 shows that the correlations between our independent variables are relatively low. Geographic distance is correlated -.60 with the shared border dummy, which is logical given their natural interrelationship. Openness is moderately correlated 
with GDP per capita at .25 , and with the time trend (.15) a finding that is in line with the process of globalization. Other than these logical correlations, all correlations are below .15.

$<$ Insert Table 3 about here $>$

Estimating our different regression equations we obtain 6 models as presented in Table 4. All models fit the data well, as their Chi-squared values are all significant $(P<0.001)$.

<Insert Table 4 about here>

No significant time-trend effects are found when explaining total intra-firm sales. The time-trend variable is insignificant when explaining inter-firm sales, providing no support for hypothesis 1 .

Now turning to the second set of hypotheses, 2a and 2b, we find a negative relationship between time-trend and the share of host-home sales, confirming that over time the share of this type of cross border sales has decreased. However, we also find a positive interaction effect, implying that the negative time-trend effect is moderated by level of economic development supporting hypothesis $2 \mathrm{~b}$. The negative main effect and the positive interaction effect also hold when explaining the share of intra-firm host-home sales. For the share of intra-firm host-host sales we find opposite results, i.e. we find a positive time-trend effect and a negative interaction effect, implying that over time the GVC specialization has increased, but that this positive trend differs between countries with different levels of economic development, indeed supporting hypothesis 2a and $2 \mathrm{~b}$. These findings suggest that total intra-firm sales have not increased, but 
the underlying structure of intra-firm sales has, that is, host-home intra-firm sales have decreased and the more 'advanced' host-host intra-firm sales have increased.

Given the significant interaction effects, we further explore the exact nature of this moderating effect of GDP per capita on the time-trend. Defining developing countries as the mean value of GDP per capita minus one standard deviation (=8.6 in log values) and developed countries as mean plus one standard deviation (=10.16), and keeping all other factors constant we plot the interaction effects of the time-trend and GDP per capita in Figure 3a and Figure 3b.

\section{$<$ Insert Figure 3a and 3b here $>$}

The dotted line reflects the relationship between the time-trend and the share of hosthome sales, respectively the share of host-host intra-firm sales for developed countries. The smoothed line plots the development of these sales shares for developing countries. In calculating the equations we assume that all variables except for the time-trend, GDP per capita (in log) and their interaction are constant. This implies that the estimated coefficients of the interaction effects and the main time-trend effect determine the slope of the curve while the starting value at the y-axis is determined by the estimated coefficient of (log) GDP per capita. We obtain two figures, both showing the development of the two sales shares between 1983 and 2003, keeping all other factors constant. Figure 3a clearly shows that the share of host-home sales has decreased for both developed and developing countries, but that the slope of the developing countries sub-sample is steeper, implying that the decrease of host-home sales especially holds for developing countries. On the other hand, Figure 3b shows that the share of host-host intra-firm sales has increased substantially for developing countries. We find a small 
negative slope - almost a horizontal curve - for the share of host-host intra-firm in developed countries, a result in line with the non-significant differences of our t-test between the 1983-1988 and the 1999-2003 period. All in all, the results suggest that the share of host-home sales has decreased, and the share of host-host intra-firm sales has increased over time, confirming our hypothesis that a shift towards GVC specialization can be observed, at least for U.S. affiliates. This result especially holds for the change from host-home intra-firm to host-host intra-firm sales.

Our other independent (control) variables mostly behave according to our expectations. As expected, we find a significantly negative effect of geographic distance in the models explaining the share of host-home sales and a significantly positive effect of geographic distance in the models explaining the share of host-host intra-firm sales. Along similar lines we obtain a significantly positive effect for the share of host-home sales in those host countries sharing a border with the United States. And again we find the opposite relationship for the share of hosthost intra-firm sales. We find a non-significant effect for host countries that are member of GATT/WTO, and mixed findings are obtained for openness.

In order to check if the changing pattern in type of cross border sales is caused by a decrease in absolute host-home sales and an increase in absolute intra-firm sales in multiple countries, we have also regressed our set of independent variables on the absolute levels of sales of both host-home sales and the host-host sales (results not shown but available upon request). We find for both types of sales that our time-trend variable is positive and significant, suggesting that both types of sales have increased in absolute terms (both $\mathrm{p}<.01$ ). Given our earlier results on their respective shares, the estimated coefficient for home host sales is logically smaller than for the host-host sales (.15 versus .28). We also find a significant negative interaction effect for 
both types of sales, confirming our previous findings on the shares of these types of sales in total cross border sales. This negative interaction effect for the absolute sales implies that the increase over time especially holds for developing countries. In other words both types of sales have increased, but the host-home sales relatively less, leading to a pattern of cross border sales that is increasingly globally specialized.

\section{Robustness analysis}

We explore the robustness of our findings by including institutional quality and wage costs of low skilled workers as additional control variables. Because of the results of our descriptive analyses and associated t-tests we also exclude the 1983 observations to see if our results hold. We include institutional quality as an additional control because if the time-trend variable picks up a general improvement of institutions over time (a phenomenon that may especially hold for developing countries), the positive effect of the time-trend variable should not be attributed to time, but to improvements in institutional quality. We measure institutional quality by the frequently used International Country Risk Guide (ICRG) ${ }^{3}$. This ICRG measure is an aggregate composite measure of 22 components all proxying different aspects of the degree of wellfunctioning of institutions. Note that the ICRG measure refers to the 'first' host, i.e. host country 1 in Figure 2. Its correlation with the time-trend variable is .27. Including the ICRG variable in our regressions does not affect our conclusion regarding the time-trend effect. The results are shown in Table 5.

$<$ Insert Table 5 about here $>$

\footnotetext{
${ }^{3}$ For more details on the underlying items and methodology we refer to: http://www.prsgroup.com/ICRG.aspx
} 
The time-trend and its associated interaction with GDP per capita remain significant with a negative main effect on host-home (intra-firm) affiliate sales and a positive main effect on hosthost intra-firm sales. The interaction effects are the opposite and confirm our previous findings. Interestingly, controlling for institutional quality yields a significant positive effect of the ICRG measure when explaining host-host inter-firm sales. In contrast with the main results reported earlier, the time-trend variable is significantly negative (insignificant in the main results) and the interaction effect between time-trend and GDP per capita is significantly positive. This suggests that over time, the share of host-host inter-firm sales has decreased, especially in developing countries, but that countries with higher levels of institutional quality do attract more of this type of cross border sales. In other words, unless developing countries have not been able to improve their institutional quality they will have experienced a reduction of U.S. affiliates exporting goods to customers in third countries from their soil.

We furthermore conducted a test including the wage costs of low skilled workers as an additional control. Because our focus is on non-market seeking U.S. outward FDI, we expect that countries with relatively low levels of labor costs, especially of low skilled labor, attract more sales. Following Braconier et al. (2005) we use data on wage costs from the Union Bank of Switzerland (UBS, various issues). ${ }^{4}$ Including the wage costs of low skilled workers does not affect our main results. The time-trend variable remains significantly negative for (intra-firm) host-home cross border sales, and its interaction with GDP per capita positive. Moreover, the

\footnotetext{
${ }^{4}$ About every three years, UBS reports annual gross wages of particular professions. Wage costs are operationalized as the hourly pre-tax income of industrial workers (toolmaker) of an, on average, 35-year old worker with three years of vocational training and at least 10 years of practical experience in a large company of the metalworking industry.
} 
time-trend variable is positive for host-host intra-firm sales and the interaction between timetrend and GDP per capita is negative and significant, again supporting hypothesis 2a and 2b.

\section{Conclusions and discussion of limitations}

In this study we have taken issue with the presumed trend towards global value chain (GVC) specialization - the GVC specialization thesis - and tested if it can be empirically supported. In the absence of large-scale activity-level measures we looked at the various flows among foreign affiliates as an alternative indicator of GVC specialization. Our study builds on the underlying logic that more specialization - that is a more advanced division of labor - among physically disparate MNE units almost inevitably infers more flows of goods, services, information, and people among the MNE affiliates. More specifically, we have theorized on both the organizational and geographical dimension of the GVC specialization thesis and meticulously distinguished between types of cross border sales flows. Using a sample of US MNEs in the 1983-2003 period we have carefully tested the trends for the different components that make up total cross border affiliate sales. To our knowledge, we are the first to provide such a careful aggregate analysis of MNE behavior over such a long period.

We contribute to the vast literature on globalization and GVC specialization by showing that against the background of a relatively stable share of cross border US affiliate sales (versus local sales) over the last two decades the share of host-home sales has decreased and the share of host-host sales has increased over time - especially for developing countries. This latter phenomenon holds especially for intra-firm sales, suggesting that the structure of cross border affiliate sales has changed in the direction of more host-host intra-firm sales.

The above findings are important because they also inform the sometimes heated policy debate on globalization by providing empirical regularities and hence, a more balanced point of 
view. Our US MNE data confirm that the share of cross border affiliate sales has not changed significantly, but the underlying structure of the cross border trade flows has. Having said so, we need to recognize at the same time that we have only studied aggregate numbers and more finegrained information on the nature of the activities involved is required to fully evaluate these developments. Ideally, we would like to have data allowing us to combine the organizational and geographical dimension with the functional (value activity) dimension. This is also important against the background of the offshoring discussion, in which it has frequently been argued that new forms of offshoring have emerged (McKinsey Global Institute, 2007; Farell, 2004, 2006; Engardio et al. 2003; Mudambi, 2008). The trade flow effects ('affiliate sales') are forwarded as indicators, or proxies, of GVC specialization in the realization that direct, activity-level measurements of MNE GVC configuration involve extreme data requirements beyond the scope of our capacity. The measurement of affiliate sales flows seems an acceptable second-best testing ground of the GVC specialization assertion. However, these sales data are not perfect. Some affiliate sales in a given year may represent production, and hence economic activity, from earlier years (BEA, 2004: M-19). Moreover, MNEs sometimes artificially increase or decrease the sales or value added by their affiliates by manipulating the transfer prices that these affiliates paid for inputs purchased from affiliated parties (Dunning, 1993: 506; Eden et al., 2005). The scale of such manipulation should have decreased in the 1990es, owing to the introduction of OECD regulation prescribing the use of transfer prices that conform to the arm's length standard. As a result, the sales data used in this study are likely to have represented the amount of US MNE activity abroad reasonably well over a large part of the 1983-2003 time period studied. An obvious limitation of our analysis concerns the use of cross border sales of US MNEs, limiting the possibility for a broader generalization of our findings. As we described in our model setup, 
similar fine-grained aggregate data for other countries do not exist, or is not made publicly available. Acknowledging this limitation, the fact that the US is the largest economy in the world and that US MNEs are generally considered to be on the forefront of the globalization trend, we have no reason to question the generalizability of our findings.

In conclusion, we have shown - using fine-grained aggregate data on cross border sales of US foreign affiliates - that the trend towards GVC specialization is reflected in the increase of the share of host-host intra firm sales, which especially holds for developing countries. This is important because it sheds new light on the underlying structure of GVC specialization of MNEs. 


\section{References}

Anderson, J.E. (1979) 'A theoretical foundation for the gravity equation', American Economic Review 69(1): 106-116.

Anderson, J.E. and Marcouiller, D. (2002) 'Insecurity and the pattern of trade: An empirical investigation', Review of Economics and Statistics 84(2): 342-352.

Antras, P., Garicano, L., and Rossi-Hansberg, E. (2006) 'Offshoring in a knowledge economy’, Quarterly Journal of Economics, 121(1): 31-77.

Asmussen, C.G., Pedersen, T. and Petersen, B. (2007) ‘How do we capture “global specialization” when measuring firms’ degree of globalization?’ Management International Review, 47(6): 1-23.

Bartlett, C.A. \& Ghoshal, S. (1989). Managing across borders. London: Century Business.

Bergstrand, J.H. (1985) 'The gravity equation in international trade: some micro economic foundations and empirical evidence', Review of Economics and Statistics 67(3): 474-481.

Braconier, H. Norback, P.J., and Urba, D. (2005) 'Multinational enterprises and wage costs: Vertical FDI revisited', Journal of International Economics 67: 446-470. 
Brainard, S.L. (1997) 'An empirical assessment of the Proximity-Concentration Trade-off between Multinational Sales and Trade', American Economic Review 87(4): 520-544.

Buckley, P. and Casson, M. (1981) 'The optimal timing of foreign direct investment', Economic Journal 91: 75-87.

Buckley, P. and Ghauri, P. (2004) Globalisation, economic geography and the strategy of multinational enterprises, Journal of International Business Studies 35: 81-98.

Carr, D, Markusen, J., \& Maskus, K.E. (2001). Estimating the knowledge capital model of the multinational enterprise. American Economic Review, 91: 693-708.

Cuervo-Cazurra, A. (2006) 'Who cares about corruption?', Journal of International Business Studies 37(6): 807-822.

Deardorff, A.V. (1979) 'Weak links in the chain of comparative advantage', Journal of International Economics, 9: 197-209.

Dicken, P. (2003). Global Shift (4 ${ }^{\text {th }}$ ed.). London: Paul Chapman Publishing.

Doh, J. (2005) 'Offshore outsourcing: implications for international business and strategic management theory and practice’, Journal of Management Studies 42(3): 695-704. 
Doz, Y. L., Santos, J. and Williamson P. (2001). From Global to Metanational: How Companies Win in the Knowledge Economy. Boston: Harvard Business School Press.

Dunning J. (1993) 'Internationalising Porter’s diamond', Management International Review, 33(2): 7-15

Dunning, J. (2000) 'The eclectic paradigm as an envelope for economic and business theories of MNE’, International Business Review, 9: 163-190.

Economic Policy Institute (2005) Trust and consequences of offshoring, Economic Policy Institute (EPI) briefing paper \# 155, Washington.

Eden, L., Juarez Valdez, L.F. and Li, D. (2005) 'Talk softly but carry a big stick: transfer pricing penalties and the market valuation of Japanese multinationals in the United States', Journal of International Business Studies 36(4): 398-414.

Engardio, P., Bernstein, A, and Kripalani, M. (2003) 'The new global job shift', Business Week, February 3.

Farell, D. (2004) 'Beyond offshoring: assess your company’s global potential', Harvard Business Review, 82(12): 82-90 
Farrell, D. (2005) 'Offshoring: value creation through economic change', Journal of Management Studies 42(3): 675-683.

Farell, D. (2006) ‘Smarter offshoring’, Harvard Business Review, 84(6): 84-92.

Frankel, J.A. (1997) Regional Trading Blocs in the World Economic System, Washington, DC: Institute for International Economics.

Frost, T.S., Birkinshaw, J.M. \& Ensign, P.C. (2000). 'Centers of excellence in multinational corporations’. Strategic Management Journal, 23: 997-1018.

Gerachi, V.C. and Prewo, W. (1977) 'Bilateral Trade Flows and Transport Costs', The Review of Economics and Statistics 59(1): 67-74.

Gereffi, G. (1999) 'International trade and industrial upgrading in the apparel commodity chain’, Journal of International Economics, 48(1): 37-70.

Ghoshal, S. (1987) ‘Global Strategy: An Organizing Framework’, Strategic Management Journal, 8(5): 425-440

Grossman, G.M. and Helpman, E. (2005) 'Outsourcing in a global economy', Review of Economic Studies, 72: 135-159. 
Habib, M. and Zurawicki, L. (2002) 'Corruption and foreign direct investment', Journal of International Business Studies 33(2): 291-307.

Harrison, A.E. and McMillan, M.S. (2006) 'Dispelling some myths about offshoring’, Academy of Management Perspectives, 20(4): 6-22.

Holm, U. \& Pedersen, T. (Eds.) (2000). The Emergence and Impact of MNC Centers of Excellence. London: Macmillan.

Huang, R.R. (2007) 'Distance and trade: Disentangling unfamiliarity effects and transport cost effects', European Economic Review 51(1): 161-181.

Humphrey, J. and Schmitz, H. (2005), 'How does insertion in global value chain affect upgrading in industrial Cluster', Regional Studies, 36(9): 1017-1027.

Kogut, B. (1985) Designing Global Strategies: Comparative and Competitive Value-Added Chains. Sloan Management Review; 26(4): 15-28.

Kotabe, M. and Murray, J.Y. (2004) 'Global Sourcing Strategy and Sustainable Competitive Advantage’ Industrial Marketing Management, 33(1): 7-14. 
Kumar, N. (1994) 'Determinants of export orientation of foreign production by US multinationals: An inter-country analysis’, Journal of International Business Studies 25(1): 141156.

Leamer, E.E. and Levinsohn, J. (1995) 'International trade theory: The evidence', in G.M. Grossman and K. Rogoff (eds.) Handbook of International Economics 3, Amsterdam: Elsevier.

Lewin, A. and Peeters, C. (2006) 'Offshoring work: business hype of the onset of fundamental transformation?’ Long Range Planning, 39: 221-239.

Levy, D.L. (2005) 'Offshoring in the new global political economy', Journal of Management Studies, 42(3): 685-693.

Linnemann, H. (1966) An econometric study of international trade flows, Amsterdam: NorthHolland Publishing Company.

Marin, D. (2006) 'A new international division of labor in Europe: outsourcing and offshoring to Eastern Europe', Journal of the European Economic Association, 4(2-3): 612-622.

Markusen, J. (1995) 'The boundaries of the multinational enterprise and theory of international trade', Journal of Economic Perspectives, 9(2), 169-189. 
McKinsey Global Institute (2007) Offshoring: understanding the emerging global labor market, edited by Diana Farrell, Harvard Business School Press.

Mudambi, R. (2008) 'Location, control and innovation in knowledge-intensive industries', Journal of Economic Geography, forthcoming.

Nachum, L. and Zaheer, S. (2005) 'The persistence of distance? The impact of technology on MNE motivations for foreign investment', Strategic Management Journal, 26(8): 747-767.

Porter, M.E. (1986). Competition in Global Industries: A Conceptual Framework. Pp. 1-33 in M.E. Porter (Ed.), Competition in Global Industries., Cambridge, MA, USA: Harvard Business School Press.

Prahalad, C.K. \& Doz, Y. (1987). The Multinational Mission: Balancing Local Demands and Global Vision. New York: Free Press.

Ramamurti, R. (2004) 'Developing countries and MNEs: extending and enriching the research agenda', Journal of International Business Studies 35(4): 277-283.

Robinson, M. and Kalakota, R. (2004) Offshore Outsourcing - Business Models, ROI and Best Practices. Alpharetta, GA: Mivar Press. 2004 
Rose, A.K. (2004) 'Do we really know that the WTO increases trade?', American Economic Review, 94(1): 98-114.

Roth, K. (1992) 'International configuration and coordination arcetypes for medium-sized firms in global industries', Journal of International Business Studies, 23(3): 533-549.

Roth, K., Schweiger, D., and Morrison, A.J. (1991) 'Global Strategy Implementation at the Business Unit Level: Operational Capabilities and Administrative Mechanisms', Journal of International Business Studies, 21(4): 541-564.

Sanchez, R. and Mahoney, J. T. (1996). 'Modularity, flexibility, and knowledge management in product and organization design', Strategic Management Journal, 17 (winter special issue): 6376.

Schmitz, H. (Ed.) (2004), Local Enterprises in the Global Economy: Issues of Governance and upgrading. Cheltenham: Edward Elgar.

Smith, D. (2006) 'Offshoring: political myths and economic reality', World Economy 29(3): 249-256.

Tinbergen, J. (1962) Shaping the world economy, New York: Twentieth Century Fund.

Venkatraman, N. (2004) 'Offshoring without guilt', Sloan Management Review, 45(3): 14-16. 
Yeaple, S. (2006) 'Offshoring, foreign direct investment, and the structure of U.S. trade', Journal of the European Economic Association, 4(2-3): 602-611.

Yip, G.S. (1989) ‘Global Strategy ... In a World of Nations?’ Sloan Management Review, 31(1): 29-41.

Williamson, O.E. (1985). The Economic Institutions of Capitalism. New York: The Free Press.

World Trade Organization (2005) International Trade Statistics 2005, Geneva: WTO Publications.

Zaheer, S. \& Manrakhan, S. (2001) 'Concentration and Dispersion in Global Industries: Remote Electronic Access and the Location of Economic Activities’ Journal of International Business Studies, 32: 667-686. 
Figure 1: Hypothesized effects of GVC specialization on affiliate sales flows

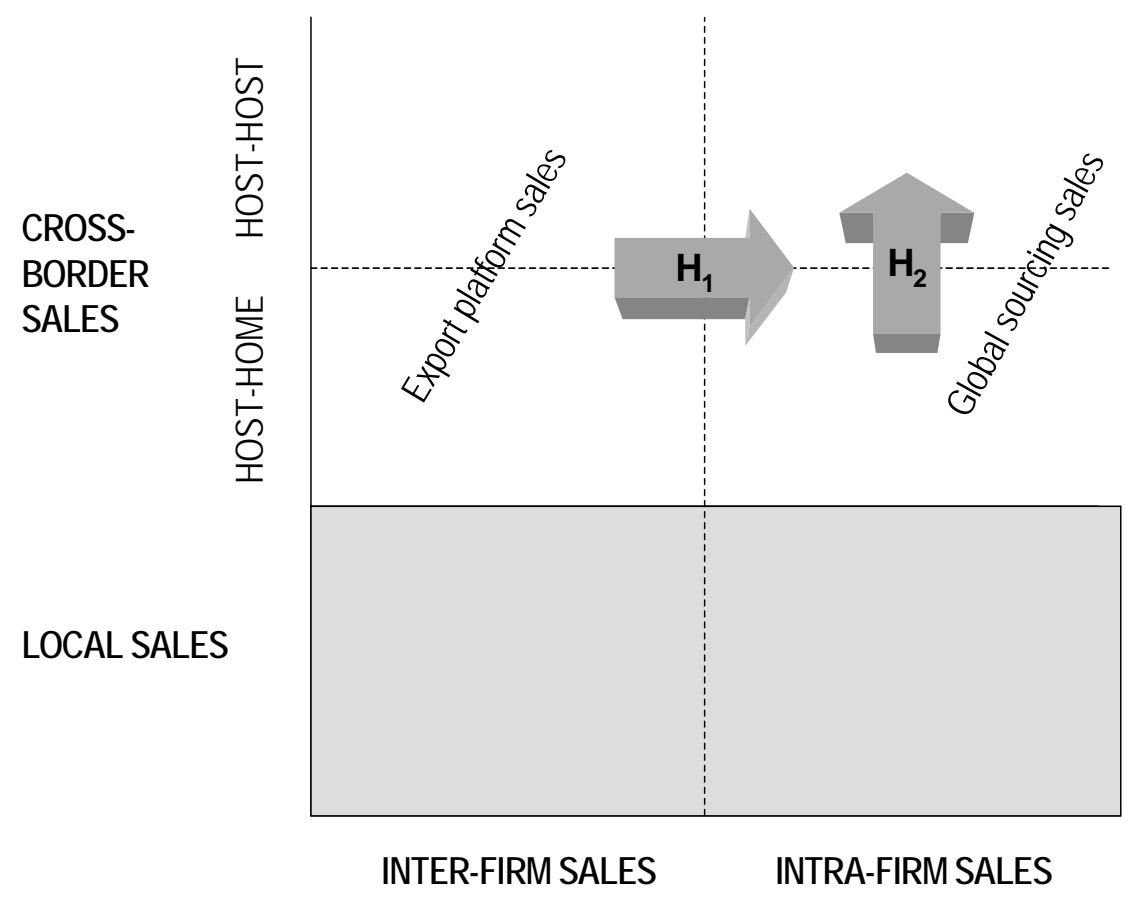


Figure 2: Categorizing cross border U.S. affiliate sales

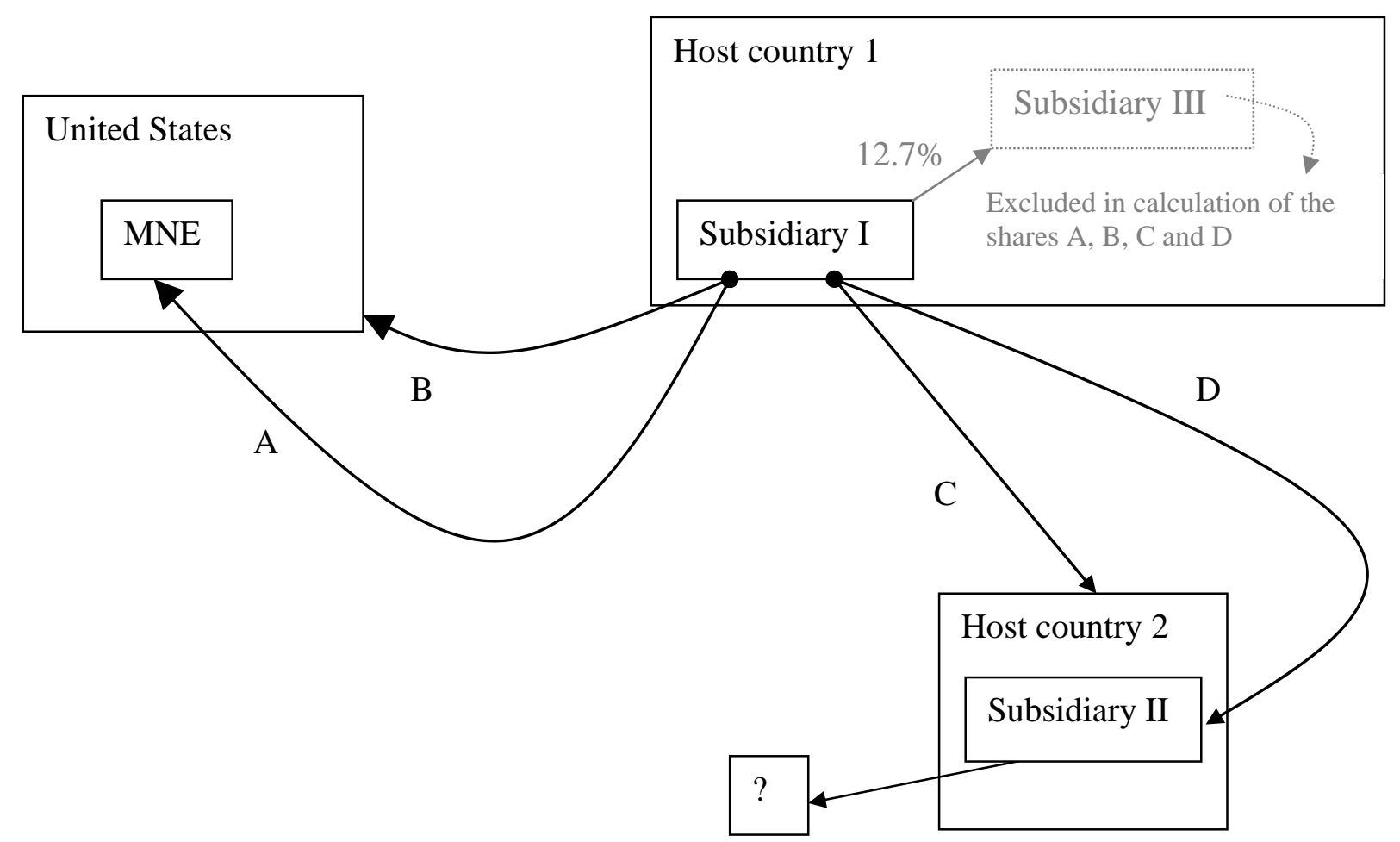

A $=$ Host-home intra-firm affiliate sales

$\mathrm{B}=$ Host-home inter-firm affiliate sales

$\mathrm{C}=$ Host-host inter-firm affiliate sales

$\mathrm{D}=$ Host-host intra-firm affiliate sales

Note that all flows are calculated as shares of the total cross border sales $(A+B+C+D)$. 
Figure 3a: time trend effect and share of host-home sales

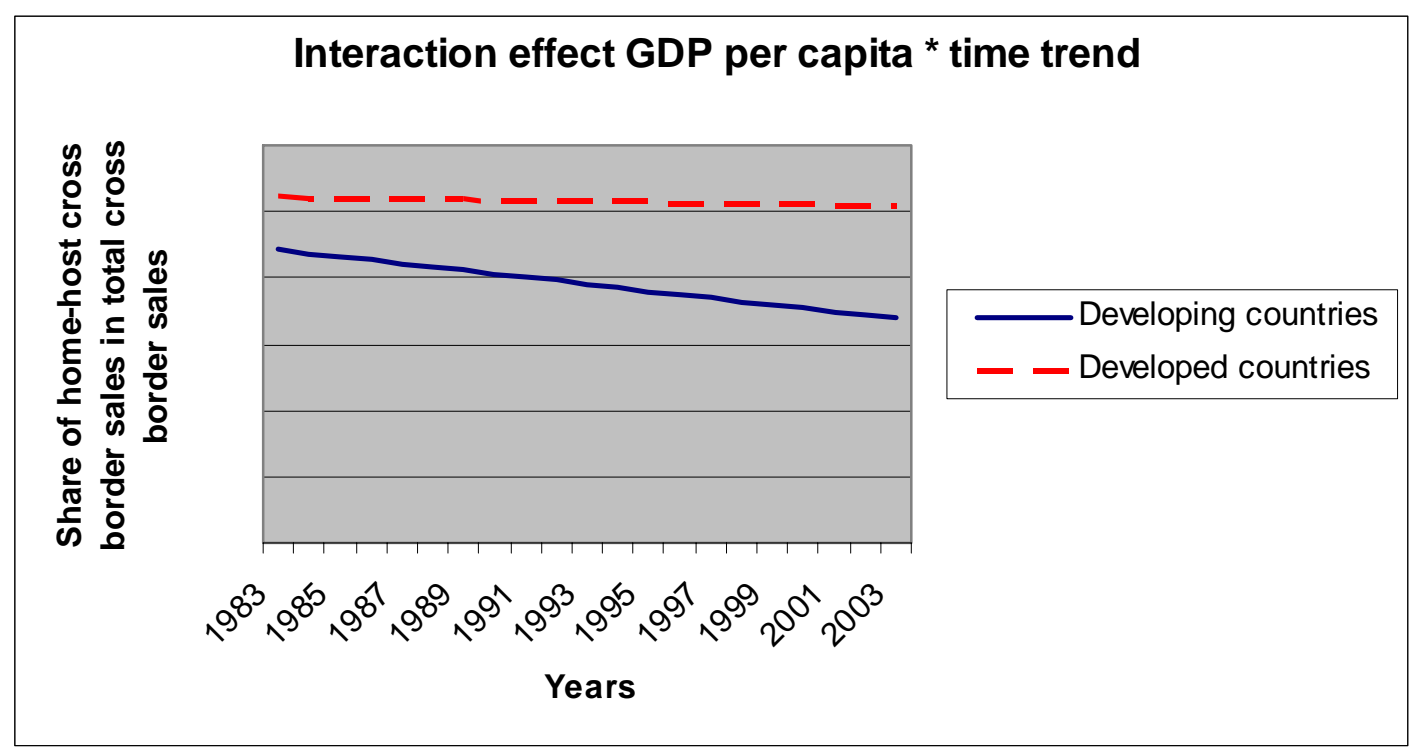

Figure 3b: time trend effect and share of host-host intra-firm sales (global value chain specialization)

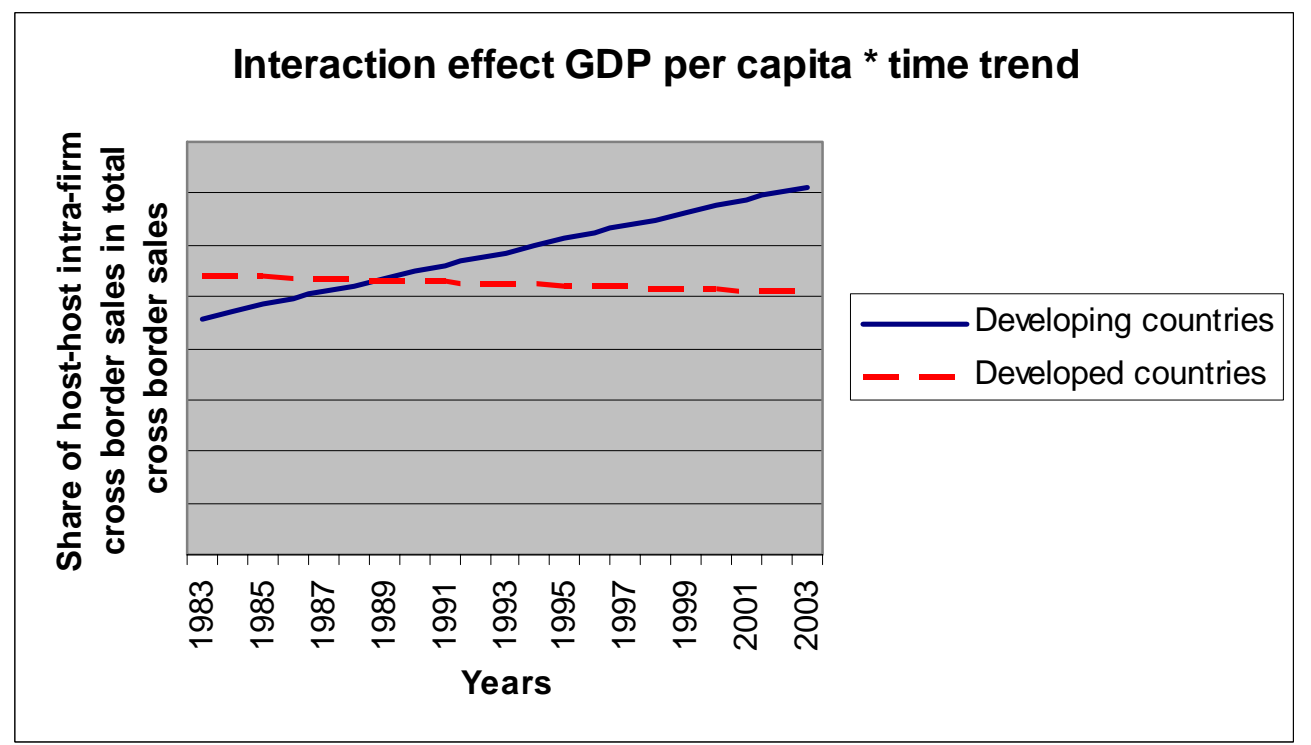


Table 1: Descriptive statistics of the local sales versus cross border sales as a share of total MNE sales

\begin{tabular}{|c|c|c|c|c|c|c|}
\hline \multirow[b]{2}{*}{ Year } & \multicolumn{2}{|c|}{ Total sample } & \multicolumn{2}{|c|}{$\begin{array}{l}\text { Developing countries (GDP per } \\
\text { capita below sample mean) }\end{array}$} & \multicolumn{2}{|c|}{$\begin{array}{l}\text { Developed countries (GDP per } \\
\text { capita above sample mean) }\end{array}$} \\
\hline & Local sales & $\begin{array}{l}\text { Cross border } \\
\text { sales }\end{array}$ & Local sales & $\begin{array}{l}\text { Cross border } \\
\text { sales }\end{array}$ & Local sales & $\begin{array}{l}\text { Cross border } \\
\text { sales }\end{array}$ \\
\hline 1983 & 0.659 & 0.341 & 0.724 & 0.276 & 0.605 & 0.395 \\
\hline 1984 & 0.632 & 0.368 & 0.73 & 0.27 & 0.548 & 0.452 \\
\hline 1985 & 0.605 & 0.395 & 0.688 & 0.312 & 0.523 & 0.477 \\
\hline 1986 & 0.615 & 0.385 & 0.674 & 0.326 & 0.561 & 0.439 \\
\hline 1987 & 0.627 & 0.373 & 0.686 & 0.314 & 0.581 & 0.419 \\
\hline 1988 & 0.599 & 0.401 & 0.741 & 0.259 & 0.512 & 0.488 \\
\hline 1989 & 0.617 & 0.383 & 0.707 & 0.293 & 0.578 & 0.422 \\
\hline 1990 & 0.615 & 0.385 & 0.69 & 0.31 & 0.565 & 0.435 \\
\hline 1991 & 0.604 & 0.396 & 0.653 & 0.347 & 0.567 & 0.433 \\
\hline 1992 & 0.626 & 0.374 & 0.698 & 0.302 & 0.589 & 0.411 \\
\hline 1993 & 0.583 & 0.417 & 0.58 & 0.42 & 0.585 & 0.415 \\
\hline 1994 & 0.641 & 0.359 & 0.63 & 0.37 & 0.651 & 0.349 \\
\hline 1995 & 0.642 & 0.358 & 0.682 & 0.318 & 0.609 & 0.391 \\
\hline 1996 & 0.604 & 0.396 & 0.632 & 0.368 & 0.584 & 0.416 \\
\hline 1997 & 0.63 & 0.37 & 0.699 & 0.301 & 0.587 & 0.413 \\
\hline 1998 & 0.62 & 0.38 & 0.66 & 0.34 & 0.596 & 0.404 \\
\hline 1999 & 0.585 & 0.415 & 0.601 & 0.399 & 0.579 & 0.421 \\
\hline 2000 & 0.61 & 0.39 & 0.697 & 0.303 & 0.571 & 0.429 \\
\hline 2001 & 0.617 & 0.383 & 0.685 & 0.315 & 0.573 & 0.427 \\
\hline 2002 & 0.614 & 0.386 & 0.709 & 0.291 & 0.53 & 0.47 \\
\hline 2003 & 0.623 & 0.377 & 0.696 & 0.304 & 0.58 & 0.42 \\
\hline Average & .617 & .382 & .679 & .321 & .575 & .425 \\
\hline Average $1^{\text {st }}$ five years & .628 & .372 & .700 & .300 & .564 & .436 \\
\hline Average last five years & .609 & .390 & .678 & .322 & .566 & .434 \\
\hline $\begin{array}{l}\text { Absolute t-value of equality of means } \\
\text { test } 1^{\text {st }} \text { five years=last five years }\end{array}$ & 0.0187 & 0.0187 & 0.2881 & 0.2881 & 0.77 & 0.77 \\
\hline $\begin{array}{l}\text { Absolute t-value of equality of means } \\
\text { (excluding 1983) }\end{array}$ & 0.4913 & 0.4913 & 0.1592 & 0.1592 & 1.1274 & 1.1274 \\
\hline
\end{tabular}


Table 2a: Descriptive statistics of the four main types of cross border sales flows as a share of total cross border sales (total sample)

\begin{tabular}{|c|c|c|c|c|c|c|}
\hline Year & $\begin{array}{l}\text { Total host- } \\
\text { home }(\mathrm{A}+\mathrm{B})\end{array}$ & $\begin{array}{l}\text { Total intra-firm } \\
(\mathrm{A}+\mathrm{D})\end{array}$ & $\begin{array}{l}\text { Host-home intra- } \\
\text { firm (A) }\end{array}$ & $\begin{array}{l}\text { Host-home inter- } \\
\text { firm (B) }\end{array}$ & $\begin{array}{l}\text { Host-host inter- } \\
\text { firm (C) }\end{array}$ & $\begin{array}{l}\text { Host-host intra- } \\
\text { firm (D) }\end{array}$ \\
\hline 1983 & 0.24 & 0.6 & 0.21 & 0.04 & 0.37 & 0.39 \\
\hline 1984 & 0.29 & 0.62 & 0.26 & 0.03 & 0.34 & 0.36 \\
\hline 1985 & 0.31 & 0.57 & 0.26 & 0.05 & 0.37 & 0.31 \\
\hline 1986 & 0.32 & 0.6 & 0.28 & 0.05 & 0.36 & 0.32 \\
\hline 1987 & 0.31 & 0.6 & 0.26 & 0.04 & 0.34 & 0.34 \\
\hline 1988 & 0.32 & 0.54 & 0.25 & 0.069 & 0.38 & 0.29 \\
\hline 1989 & 0.33 & 0.597 & 0.27 & 0.056 & 0.337 & 0.327 \\
\hline 1990 & 0.312 & 0.626 & 0.258 & 0.054 & 0.319 & 0.368 \\
\hline 1991 & 0.283 & 0.642 & 0.235 & 0.047 & 0.309 & 0.407 \\
\hline 1992 & 0.223 & 0.579 & 0.184 & 0.038 & 0.381 & 0.395 \\
\hline 1993 & 0.275 & 0.622 & 0.234 & 0.041 & 0.337 & 0.388 \\
\hline 1994 & 0.303 & 0.638 & 0.272 & 0.031 & 0.329 & 0.366 \\
\hline 1995 & 0.251 & 0.621 & 0.211 & 0.041 & 0.338 & 0.41 \\
\hline 1996 & 0.264 & 0.625 & 0.227 & 0.037 & 0.337 & 0.398 \\
\hline 1997 & 0.265 & 0.61 & 0.226 & 0.039 & 0.349 & 0.384 \\
\hline 1998 & 0.269 & 0.625 & 0.236 & 0.033 & 0.34 & 0.389 \\
\hline 1999 & 0.273 & 0.661 & 0.242 & 0.031 & 0.307 & 0.419 \\
\hline 2000 & 0.284 & 0.634 & 0.235 & 0.048 & 0.312 & 0.399 \\
\hline 2001 & 0.235 & 0.582 & 0.191 & 0.043 & 0.373 & 0.391 \\
\hline 2002 & 0.278 & 0.664 & 0.241 & 0.037 & 0.297 & 0.423 \\
\hline 2003 & 0.247 & 0.628 & 0.208 & 0.039 & 0.333 & 0.42 \\
\hline Average & .28 & .62 & .24 & .04 & .34 & .38 \\
\hline Average $1^{\text {st }}$ five years & .294 & .598 & .254 & .042 & .356 & .344 \\
\hline Average last five years & .263 & .634 & .223 & .0396 & .324 & .410 \\
\hline $\begin{array}{l}\text { Absolute t-value of equality of means } \\
\text { test } 1^{\text {st }} \text { five years=last five years }\end{array}$ & 1.06 & $1.96^{* *}$ & .953 & 678 & $1.876^{*}$ & $2.969 * * *$ \\
\hline $\begin{array}{l}\text { Absolute t-value of equality of means } \\
\text { (excluding 1983) }\end{array}$ & $2.29 * *$ & 1.42 & 1.469 & .449 & 1.364 & $3.026 * * *$ \\
\hline
\end{tabular}

*** $P<0.01$, ** $P<0.05$, * $P<0.10$ (two-tailed). The t-test is performed on all yearly observations and is unpaired because of the missing observations for some years. Equal variances are assumed. 
Table 2b: Descriptive statistics of the four main types of cross border sales flows as a share of total cross border sales for

developing countries (GDP per capita below sample mean)

\begin{tabular}{|c|c|c|c|c|c|c|}
\hline Year & $\begin{array}{l}\text { Total host- } \\
\text { home }(\mathrm{A}+\mathrm{B})\end{array}$ & $\begin{array}{l}\text { Total intra-firm } \\
(\mathrm{A}+\mathrm{D})\end{array}$ & $\begin{array}{l}\text { Host-home intra- } \\
\text { firm (A) }\end{array}$ & $\begin{array}{l}\text { Host-home inter- } \\
\text { firm (B) }\end{array}$ & $\begin{array}{l}\text { Host-host inter- } \\
\text { firm (C) }\end{array}$ & $\begin{array}{l}\text { Host-host intra- } \\
\text { firm (D) }\end{array}$ \\
\hline 1983 & 0.302 & 0.584 & 0.245 & 0.058 & 0.357 & 0.339 \\
\hline 1984 & 0.366 & 0.645 & 0.322 & 0.043 & 0.31 & 0.323 \\
\hline 1985 & 0.415 & 0.573 & 0.34 & 0.067 & 0.351 & 0.233 \\
\hline 1986 & 0.419 & 0.636 & 0.372 & 0.047 & 0.315 & 0.264 \\
\hline 1987 & 0.428 & 0.677 & 0.38 & 0.048 & 0.274 & 0.297 \\
\hline 1988 & 0.395 & 0.538 & 0.286 & 0.109 & 0.351 & 0.252 \\
\hline 1989 & 0.386 & 0.571 & 0.303 & 0.082 & 0.344 & 0.268 \\
\hline 1990 & 0.385 & 0.592 & 0.311 & 0.073 & 0.333 & 0.281 \\
\hline 1991 & 0.367 & 0.681 & 0.31 & 0.056 & 0.261 & 0.371 \\
\hline 1992 & 0.261 & 0.603 & 0.222 & 0.038 & 0.356 & 0.381 \\
\hline 1993 & 0.369 & 0.652 & 0.319 & 0.051 & 0.296 & 0.333 \\
\hline 1994 & 0.424 & 0.673 & 0.387 & 0.037 & 0.288 & 0.286 \\
\hline 1995 & 0.306 & 0.588 & 0.255 & 0.05 & 0.361 & 0.333 \\
\hline 1996 & 0.397 & 0.668 & 0.347 & 0.049 & 0.281 & 0.321 \\
\hline 1997 & 0.388 & 0.613 & 0.337 & 0.051 & 0.335 & 0.276 \\
\hline 1998 & 0.411 & 0.641 & 0.363 & 0.047 & 0.311 & 0.278 \\
\hline 1999 & 0.399 & 0.708 & 0.362 & 0.036 & 0.253 & 0.346 \\
\hline 2000 & 0.335 & 0.643 & 0.252 & 0.082 & 0.273 & 0.391 \\
\hline 2001 & 0.259 & 0.599 & 0.206 & 0.053 & 0.347 & 0.393 \\
\hline 2002 & 0.319 & 0.716 & 0.277 & 0.041 & 0.241 & 0.439 \\
\hline 2003 & 0.318 & 0.67 & 0.267 & 0.051 & 0.278 & 0.403 \\
\hline Average & .36 & .63 & .31 & .055 & .31 & .32 \\
\hline Average $1^{\text {st }}$ five years & .386 & .623 & .332 & .053 & .32 & .29 \\
\hline Average last five years & .326 & .667 & .272 & .053 & .278 & .39 \\
\hline $\begin{array}{l}\text { Absolute t-value of equality of means } \\
\text { test } 1^{\text {st }} \text { five years=last five years }\end{array}$ & $1.784 *$ & .963 & $1.79 *$ & .01 & 1.09 & $2.969 * * *$ \\
\hline $\begin{array}{l}\text { Absolute t-value of equality of means } \\
\text { (excluding 1983) }\end{array}$ & $2.294 * *$ & .566 & $2.31^{* *}$ & .053 & .61 & $3.158 * * *$ \\
\hline
\end{tabular}

*** $P<0.01$, ** $P<0.05,{ }^{*} P<0.10$ (two-tailed). The t-test is performed on all yearly observations and is unpaired because of the missing observations for some

years. Equal variances are assumed. 
Table 2c: Descriptive statistics of the four main types of cross border sales flows as a share of total cross border sales for developed countries (GDP per capita above sample mean)

\begin{tabular}{|c|c|c|c|c|c|c|}
\hline Year & $\begin{array}{l}\text { Total host- } \\
\text { home }(\mathrm{A}+\mathrm{B})\end{array}$ & $\begin{array}{l}\text { Total intra-firm } \\
(\mathrm{A}+\mathrm{D})\end{array}$ & $\begin{array}{l}\text { Host-home intra- } \\
\text { firm (A) }\end{array}$ & $\begin{array}{l}\text { Host-home inter- } \\
\text { firm (B) }\end{array}$ & $\begin{array}{l}\text { Host-host inter- } \\
\text { firm (C) }\end{array}$ & $\begin{array}{l}\text { Host-host intra- } \\
\text { firm (D) }\end{array}$ \\
\hline 1983 & 0.199 & 0.596 & 0.171 & 0.027 & 0.375 & 0.425 \\
\hline 1984 & 0.241 & 0.606 & 0.214 & 0.027 & 0.367 & 0.392 \\
\hline 1985 & 0.21 & 0.566 & 0.174 & 0.036 & 0.397 & 0.392 \\
\hline 1986 & 0.236 & 0.561 & 0.191 & 0.045 & 0.393 & 0.37 \\
\hline 1987 & 0.214 & 0.562 & 0.173 & 0.042 & 0.396 & 0.389 \\
\hline 1988 & 0.275 & 0.551 & 0.23 & 0.045 & 0.402 & 0.321 \\
\hline 1989 & 0.312 & 0.62 & 0.267 & 0.045 & 0.334 & 0.353 \\
\hline 1990 & 0.263 & 0.648 & 0.222 & 0.041 & 0.311 & 0.426 \\
\hline 1991 & 0.218 & 0.602 & 0.167 & 0.041 & 0.345 & 0.435 \\
\hline 1992 & 0.204 & 0.567 & 0.165 & 0.038 & 0.393 & 0.402 \\
\hline 1993 & 0.199 & 0.598 & 0.167 & 0.033 & 0.369 & 0.431 \\
\hline 1994 & 0.195 & 0.606 & 0.168 & 0.03 & 0.366 & 0.438 \\
\hline 1995 & 0.206 & 0.648 & 0.173 & 0.032 & 0.319 & 0.475 \\
\hline 1996 & 0.167 & 0.594 & 0.139 & 0.027 & 0.378 & 0.455 \\
\hline 1997 & 0.182 & 0.608 & 0.15 & 0.031 & 0.36 & 0.458 \\
\hline 1998 & 0.184 & 0.615 & 0.159 & 0.024 & 0.359 & 0.456 \\
\hline 1999 & 0.224 & 0.644 & 0.196 & 0.028 & 0.327 & 0.448 \\
\hline 2000 & 0.259 & 0.63 & 0.227 & 0.031 & 0.337 & 0.403 \\
\hline 2001 & 0.219 & 0.57 & 0.182 & 0.036 & 0.392 & 0.388 \\
\hline 2002 & 0.242 & 0.618 & 0.208 & 0.033 & 0.348 & 0.41 \\
\hline 2003 & 0.205 & 0.604 & 0.173 & 0.031 & 0.364 & 0.431 \\
\hline Average & .22 & .60 & .18 & .034 & .36 & .41 \\
\hline Average $1^{\text {st }}$ five years & .22 & .578 & .18 & .035 & .385 & .39 \\
\hline Average last five years & .23 & .613 & .20 & .032 & .354 & .41 \\
\hline $\begin{array}{l}\text { Absolute t-value of equality of means } \\
\text { test } 1^{\text {st }} \text { five years=last five years }\end{array}$ & .478 & $2.15^{* *}$ & .70 & .943 & $1.934^{*}$ & 1.11 \\
\hline $\begin{array}{l}\text { Absolute t-value of equality of means } \\
\text { (excluding 1983) }\end{array}$ & .078 & $1.759 *$ & .287 & 1.064 & 1.509 & 1.197 \\
\hline
\end{tabular}

*** $P<0.01$, ** $P<0.05, * P<0.10$ (two-tailed). The t-test is performed on all yearly observations and is unpaired because of the missing observations for some years. Equal variances are assumed. 
Table 3: Descriptive statistics of the regression analysis

\begin{tabular}{|c|c|c|c|c|c|c|c|c|c|c|c|c|c|}
\hline 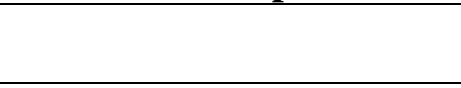 & Mean & $\begin{array}{l}\text { St. } \\
\text { dev. }\end{array}$ & 1 & 2 & 3 & 4 & 5 & 6 & 7 & 8 & 9 & 10 & 11 \\
\hline 1. Total Host-home FDI & 28.0 & 23.9 & 1 & & & & & & & & & & \\
\hline 2. Total Intra-firm FDI & 61.5 & 21.3 & .38 & 1 & & & & & & & & & \\
\hline 3. Host-home Intra-firm FDI & 23.8 & 22.3 & .97 & .50 & 1 & & & & & & & & \\
\hline 4. Host-home inter-firm FDI & 4.3 & 6.0 & .38 & -.33 & .14 & 1 & & & & & & & \\
\hline 5. Host-host inter-firm FDI & 34.1 & 20.1 & -.51 & -.95 & -.57 & .06 & 1 & & & & & & \\
\hline 6. Host-host intra-firm FDI & 37.8 & 22.0 & -.61 & .47 & -.54 & -.47 & -.36 & 1 & & & & & \\
\hline 7. Time-trend & 11.33 & 6.04 & -.07 & .07 & -.06 & -.06 & -.05 & .12 & 1 & & & & \\
\hline 8. GDP per capita (log) & 9.37 & .792 & -.30 & -.10 & -.29 & -.14 & .14 & .20 & .13 & 1 & & & \\
\hline 9. Geographic distance (log) & 8.83 & .656 & -.32 & -.10 & -.26 & -.28 & .18 & .18 & -.03 & -.09 & 1 & & \\
\hline 10. Openness (log) & 3.92 & .67 & .05 & .03 & .07 & -.08 & -.00 & -.05 & .15 & .25 & .05 & 1 & \\
\hline 11. Shared border/Nafta dummy & .05 & .22 & .56 & .23 & .54 & .26 & -.32 & -.33 & -.00 & .09 & -.60 & -.01 & 1 \\
\hline 12. GATT/WTO dummy & .94 & .24 & -.11 & .10 & -.09 & -.10 & -.07 & .19 & .08 & .14 & .08 & -.01 & .03 \\
\hline
\end{tabular}


Table 4: Explaining shares of types of cross border sales flows in total cross border flows; main results

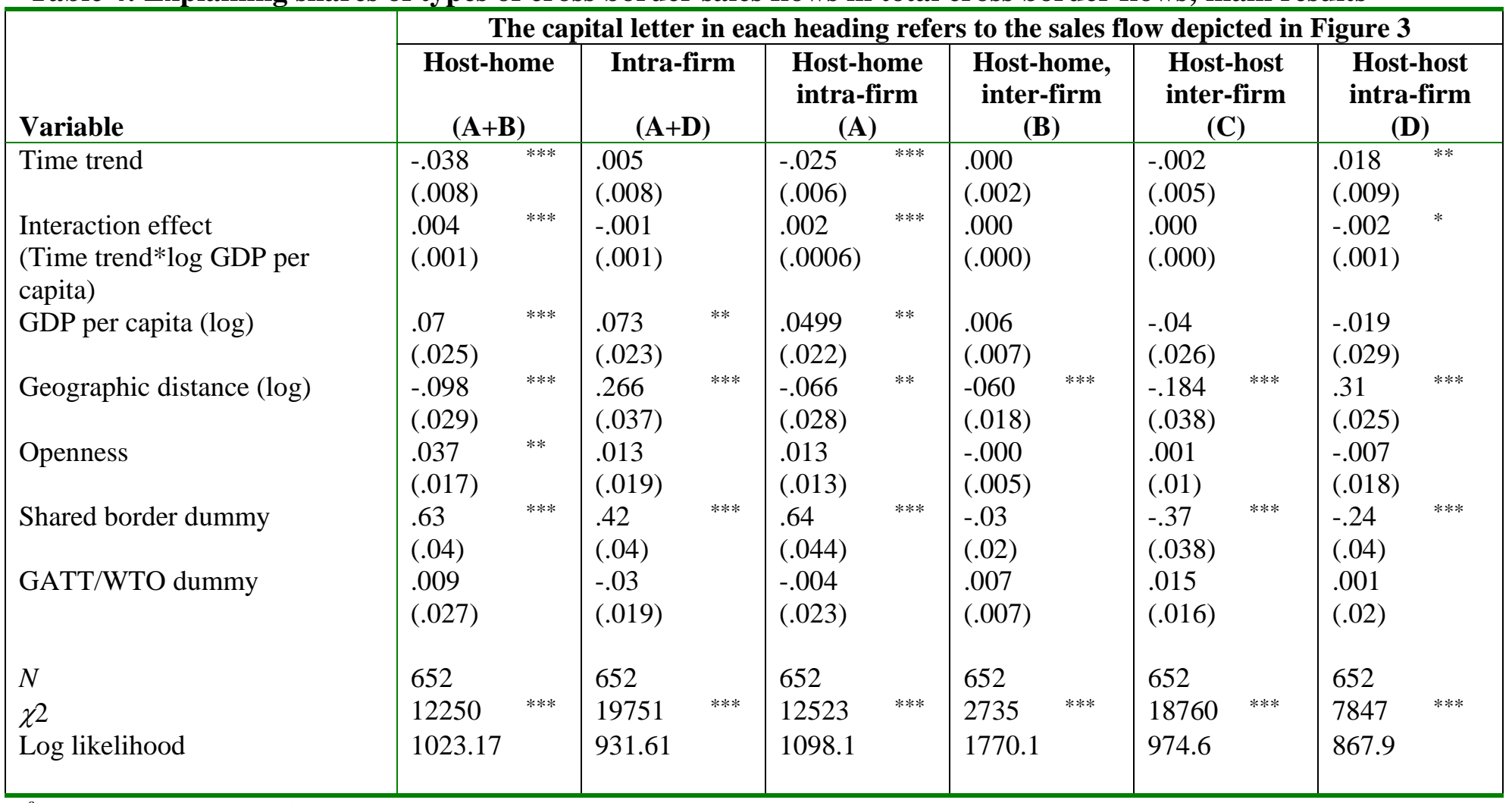

${ }^{\mathrm{a}}$ Country and year dummies and intercept are not shown. Standard errors in parentheses.

*** $P<0.01, * * P<0.05, * P<0.10$ (two-tailed).

Notes:

- The different cross border sales types are calculated as shares in total cross border sales.

- Given that Host-home is equal to $100 \%$ minus Host-Host, the estimated coefficients are equal, but the signs are reversed. Therefore we do not estimate Host-

Host separately. For similar reasons we only show the results of total intra firm FDI (equal to flow A+D in Figure 1) because the share of Inter-firm flows is equal to $100 \%$ minus the share of total intra firm flows. 
Table 5: Additional control: institutional quality (International Country Risk Guide score of the $1^{\text {st }}$ host)

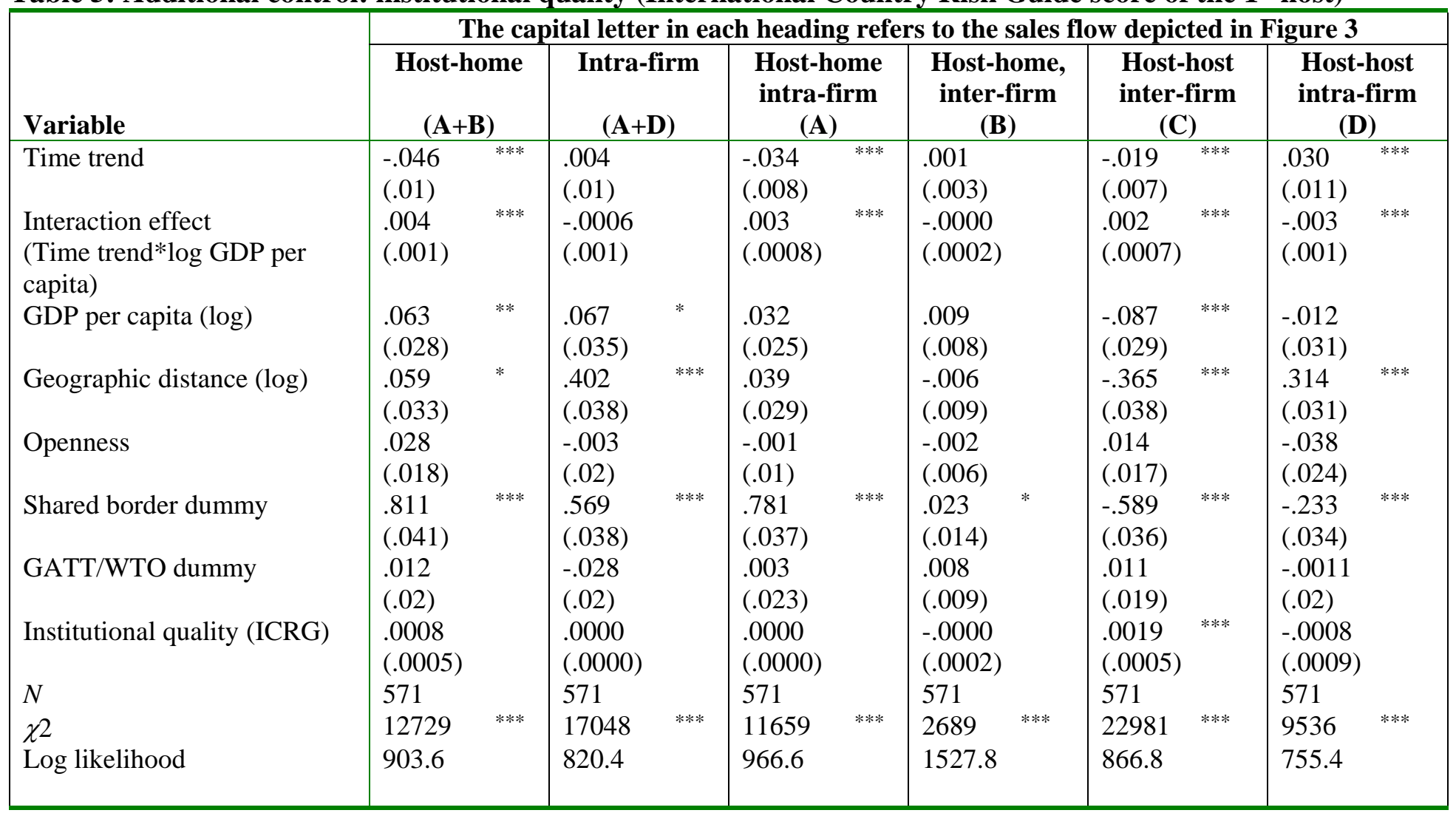

${ }^{\mathrm{a}}$ Country and year dummies and intercept are not shown. Standard errors in parentheses.

*** $P<0.01,{ }^{* *} P<0.05, * P<0.10$ (two-tailed). 
Appendix A: List of countries included in the analysis

\begin{tabular}{ll} 
Argentina & Israel \\
Australia & Italy \\
Austria & Jamaica \\
Bahamas & Japan \\
Barbados & Malaysia \\
Belgium & Mexico \\
Bermuda & Netherlands \\
Brazil & New Zealand \\
Canada & Nigeria \\
Chile & Norway \\
China & Panama \\
Colombia & Peru \\
Costa Rica & Philippines \\
Czech Republic & Poland \\
Dominican Republic & Portugal \\
Ecuador & Russia \\
Egypt & Saudi Arabia \\
Finland & Singapore \\
France & South Africa \\
Germany & South Korea \\
Greece & Spain \\
Guatemala & Sweden \\
Honduras & Switzerland \\
Hong Kong & Thailand \\
Hungary & Turkey \\
India & United Arab Emirates \\
Indonesia & United Kingdom \\
Ireland & Venezuela \\
\hline
\end{tabular}




\section{SMG - Working Papers \\ www.cbs.dk/smg \\ 2003}

2003-1: Nicolai J. Foss, Kenneth Husted, Snejina Michailova, and Torben Pedersen: Governing Knowledge Processes: Theoretical Foundations and Research Opportunities.

2003-2: Yves Doz, Nicolai J. Foss, Stefanie Lenway, Marjorie Lyles, Silvia Massini, Thomas P. Murtha and Torben Pedersen: Future Frontiers in International Management Research: Innovation, Knowledge Creation, and Change in Multinational Companies.

2003-3: Snejina Michailova and Kate Hutchings: The Impact of In-Groups and OutGroups on Knowledge Sharing in Russia and China CKG Working Paper.

2003-4: Nicolai J. Foss and Torben Pedersen: The MNC as a Knowledge Structure: The Roles of Knowledge Sources and Organizational Instruments in MNC Knowledge Management CKG Working Paper.

2003-5: Kirsten Foss, Nicolai J. Foss and Xosé H. Vázquez-Vicente: “Tying the Manager's Hands": How Firms Can Make Credible Commitments That Make Opportunistic Managerial Intervention Less Likely CKG Working Paper.

2003-6: Marjorie Lyles, Torben Pedersen and Bent Petersen: Knowledge Gaps: The Case of Knowledge about Foreign Entry.

2003-7: Kirsten Foss and Nicolai J. Foss: The Limits to Designed Orders: Authority under "Distributed Knowledge" CKG Working Paper.

2003-8: Jens Gammelgaard and Torben Pedersen: Internal versus External Knowledge Sourcing of Subsidiaries - An Organizational Trade-Off.

2003-9: Kate Hutchings and Snejina Michailova: Facilitating Knowledge Sharing in Russian and Chinese Subsidiaries: The Importance of Groups and Personal Networks Accepted for publication in Journal of Knowledge Management.

2003-10: Volker Mahnke, Torben Pedersen and Markus Verzin: The Impact of Knowledge Management on MNC Subsidiary Performance: the Role of Absorptive Capacity CKG Working Paper.

2003-11: Tomas Hellström and Kenneth Husted: Mapping Knowledge and Intellectual Capital in Academic Environments: A Focus Group Study Accepted for publication in Journal of Intellectual Capital CKG Working Paper.

2003-12: Nicolai J Foss: Cognition and Motivation in the Theory of the Firm: Interaction or "Never the Twain Shall Meet"? Accepted for publication in Journal des Economistes et des Etudes Humaines CKG Working Paper.

2003-13: Dana Minbaeva and Snejina Michailova: Knowledge Transfer and Expatriation Practices in MNCs: The Role of Disseminative Capacity.

2003-14: Christian Vintergaard and Kenneth Husted: Enhancing Selective Capacity Through Venture Bases. 


\section{4}

2004-1: Nicolai J. Foss: Knowledge and Organization in the Theory of the Multinational Corporation: Some Foundational Issues

2004-2: Dana B. Minbaeva: HRM Practices and MNC Knowledge Transfer

2004-3: Bo Bernhard Nielsen and Snejina Michailova: Toward a Phase-Model of Global Knowledge Management Systems in Multinational Corporations

2004-4: Kirsten Foss \& Nicolai J Foss: The Next Step in the Evolution of the RBV: Integration with Transaction Cost Economics

2004-5: Teppo Felin \& Nicolai J. Foss: Methodological Individualism and the Organizational Capabilities Approach

2004-6: Jens Gammelgaard, Kenneth Husted, Snejina Michailova: Knowledge-sharing Behavior and Post-acquisition Integration Failure

2004-7: Jens Gammelgaard: Multinational Exploration of Acquired R\&D Activities

2004-8: Christoph Dörrenbächer \& Jens Gammelgaard: Subsidiary Upgrading? Strategic Inertia in the Development of German-owned Subsidiaries in Hungary

2004-9: Kirsten Foss \& Nicolai J. Foss: Resources and Transaction Costs: How the Economics of Property Rights Furthers the Resource-based View

2004-10: Jens Gammelgaard \& Thomas Ritter: The Knowledge Retrieval Matrix: Codification and Personification as Separate Strategies

2004-11: Nicolai J. Foss \& Peter G. Klein: Entrepreneurship and the Economic Theory of the Firm: Any Gains from Trade?

2004-12: Akshey Gupta \& Snejina Michailova: Knowledge Sharing in Knowledge-Intensive Firms: Opportunities and Limitations of Knowledge Codification

2004-13: Snejina Michailova \& Kate Hutchings: Knowledge Sharing and National Culture: A Comparison Between China and Russia

\section{5}

2005-1: Keld Laursen \& Ammon Salter: My Precious - The Role of Appropriability Strategies in Shaping Innovative Performance

2005-2: Nicolai J. Foss \& Peter G. Klein: The Theory of the Firm and Its Critics: A Stocktaking and Assessment

2005-3: Lars Bo Jeppesen \& Lars Frederiksen: Why Firm-Established User Communities Work for Innovation: The Personal Attributes of Innovative Users in the Case of Computer-Controlled Music

2005-4: Dana B. Minbaeva: Negative Impact of HRM Complementarity on Knowledge Transfer in MNCs

2005-5: Kirsten Foss, Nicolai J. Foss, Peter G. Klein \& Sandra K. Klein: Austrian Capital 
Theory and the Link Between Entrepreneurship and the Theory of the Firm

2005-1: Nicolai J. Foss: The Knowledge Governance Approach

2005-2: Torben J. Andersen: Capital Structure, Environmental Dynamism, Innovation Strategy, and Strategic Risk Management

2005-3: Torben J. Andersen: A Strategic Risk Management Framework for Multinational Enterprise

2005-4: Peter Holdt Christensen: Facilitating Knowledge Sharing: A Conceptual Framework

2005-5 Kirsten Foss \& Nicolai J. Foss: Hands Off! How Organizational Design Can Make Delegation Credible

2005-6 Marjorie A. Lyles, Torben Pedersen \& Bent Petersen: Closing the Knowledge Gap in Foreign Markets - A Learning Perspective

2005-7 Christian Geisler Asmussen, Torben Pedersen \& Bent Petersen: How do we Capture "Global Specialization" when Measuring Firms' Degree of internationalization?

2005-8 Kirsten Foss \& Nicolai J. Foss: Simon on Problem-Solving: Implications for New Organizational Forms

2005-9 Birgitte Grøgaard, Carmine Gioia \& Gabriel R.G. Benito: An Empirical Investigation of the Role of Industry Factors in the Internationalization Patterns of Firms

2005-10 Torben J. Andersen: The Performance and Risk Management Implications of Multinationality: An Industry Perspective

2005-11 Nicolai J. Foss: The Scientific Progress in Strategic Management: The case of the Resource-based view

2005-12 Koen H. Heimeriks: Alliance Capability as a Mediator Between Experience and Alliance Performance: An Empirical Investigation Into the Alliance Capability Development Process

2005-13 Koen H. Heimeriks, Geert Duysters \& Wim Vanhaverbeke: Developing Alliance Capabilities: An Empirical Study

2005-14 JC Spender: Management, Rational or Creative? A Knowledge-Based Discussion

\section{6}

2006-1: Nicolai J. Foss \& Peter G. Klein: The Emergence of the Modern Theory of the Firm

2006-2: Teppo Felin \& Nicolai J. Foss: Individuals and Organizations: Thoughts on a Micro-Foundations Project for Strategic Management and Organizational Analysis

2006-3: Volker Mahnke, Torben Pedersen \& Markus Venzin: Does Knowledge Sharing 
Pay? An MNC Subsidiary Perspective on Knowledge Outflows

2006-4: Torben Pedersen: Determining Factors of Subsidiary Development

2006-5 Ibuki Ishikawa: The Source of Competitive Advantage and Entrepreneurial Judgment in the RBV: Insights from the Austrian School Perspective

2006-6 Nicolai J. Foss \& Ibuki Ishikawa: Towards a Dynamic Resource-Based View: Insights from Austrian Capital and Entrepreneurship Theory

2006-7 Kirsten Foss \& Nicolai J. Foss: Entrepreneurship, Transaction Costs, and Resource Attributes

2006-8 Kirsten Foss, Nicolai J. Foss \& Peter G. Klein: Original and Derived Judgement: An Entrepreneurial Theory of Economic Organization

2006-9 Mia Reinholt: No More Polarization, Please! Towards a More Nuanced Perspective on Motivation in Organizations

2006-10 Angelika Lindstrand, Sara Melen \& Emilia Rovira: Turning social capital into business? A study of Swedish biotech firms' international expansion

2006-11 Christian Geisler Asmussen, Torben Pedersen \& Charles Dhanaraj: Evolution of Subsidiary Competences: Extending the Diamond Network Model

2006-12 John Holt, William R. Purcell, Sidney J. Gray \& Torben Pedersen: Decision Factors Influencing MNEs Regional Headquarters Location Selection Strategies

2006-13 Peter Maskell, Torben Pedersen, Bent Petersen \& Jens Dick-Nielsen: Learning Paths to Offshore Outsourcing - From Cost Reduction to Knowledge Seeking

2006-14 Christian Geisler Asmussen: Local, Regional or Global? Quantifying MNC Geographic Scope

2006-15 Christian Bjørnskov \& Nicolai J. Foss: Economic Freedom and Entrepreneurial Activity: Some Cross-Country Evidence

2006-16 Nicolai J. Foss \& Giampaolo Garzarelli: Institutions as Knowledge Capital: Ludwig M. Lachmann's Interpretative Institutionalism

2006-17 Koen H. Heimriks \& Jeffrey J. Reuer: How to Build Alliance Capabilities

2006-18 Nicolai J. Foss, Peter G. Klein, Yasemin Y. Kor \& Joseph T. Mahoney: Entrepreneurship, Subjectivism, and the Resource - Based View: Towards a New Synthesis

2006-19 Steven Globerman \& Bo B. Nielsen: Equity Versus Non-Equity International Strategic Alliances: The Role of Host Country Governance

\section{7}

2007-1 Peter Abell, Teppo Felin \& Nicolai J. Foss: Building Micro-Foundations for the Routines, Capabilities, and Performance Links 
2007-2 Michael W. Hansen, Torben Pedersen \& Bent Petersen: MNC Strategies and Linkage Effects in Developing Countries

2007-3 Niron Hashai, Christian G. Asmussen, Gabriel R.G. Benito \& Bent Petersen: Predicting the Diversity of Foreign Entry Modes

2007-4 Peter D. Ørberg Jensen \& Torben Pedersen: Whether and What to Offshore?

2007-5 Ram Mudambi \& Torben Pedersen: Agency Theory and Resource Dependency Theory: Complementary Explanations for Subsidiary Power in Multinational Corporations

2007-6 Nicolai J. Foss: Strategic Belief Management

2007-7 Nicolai J. Foss: Theory of Science Perspectives on Strategic Management Research: Debates and a Novel View

2007-8 Dana B. Minbaeva: HRM Practices and Knowledge Transfer in MNCs

2007-9 Nicolai J. Foss: Knowledge Governance in a Dynamic Global Context: The Center for Strategic Management and Globalization at the Copenhagen Business School

2007-10 Paola Gritti \& Nicolai J. Foss: Customer Satisfaction and Competencies: An Econometric Study of an Italian Bank

2007-11 Nicolai J. Foss \& Peter G. Klein: Organizational Governance

2007-12 Torben Juul Andersen \& Bo Bernhard Nielsen: The Effective Ambidextrous Organization: A Model of Integrative Strategy Making Processes.

\section{8}

2008-1 Kirsten Foss \& Nicolai J. Foss: Managerial Authority When Knowledge is Distributed: A Knowledge Governance Perspective

2008-2 Nicolai J. Foss: Human Capital and Transaction Cost Economics.

2008-3 Nicolai J. Foss \& Peter G. Klein: Entrepreneurship and Heterogeneous Capital.

2008-4 Nicolai J. Foss \& Peter G. Klein: The Need for an Entrepreneurial Theory of the Firm.

2008-5 Nicolai J. Foss \& Peter G. Klein: Entrepreneurship: From Opportunity Discovery to Judgment.

2008-6 Mie Harder: How do Rewards and Management Styles Influence the Motivation to Share Knowledge?

2008-7 Bent Petersen, Lawrence S. Welch \& Gabriel R.G. Benito: Managing the Internalisation Process - A Theoretical Perspective.

2008-8 Torben Juul Andersen: Multinational Performance and Risk Management Effects: Capital Structure Contingencies. 
2008-9 Bo Bernard Nielsen: Strategic Fit and the Role of Contractual and Procedural Governance in Alliances: A Dynamic Perspective.

2008-10 Line Gry Knudsen \& Bo Bernhard Nielsen: Collaborative Capability in R\&D Alliances: Exploring the Link between Organizational and Individual level Factors.

2008-11 Torben Juul Andersen \& Mahesh P. Joshi: Strategic Orientations of Internationalizing Firms: A Comparative Analysis of Firms Operating in Technology Intensive and Common Goods Industries.

2008-12 Dana Minbaeva: HRM Practices Affecting Extrinsic and Intrinsic Motivation of Knowledge Receivers and their Effect on Intra-MNC Knowledge Transfer.

2008-13 Steen E. Navrbjerg \& Dana Minbaeva: HRM and IR in Multinational Corporations: Uneasy Bedfellows?

2008-14 Kirsten Foss \& Nicolai J. Foss: Hayekian Knowledge Problems in Organizational Theory.

2008-15 Torben Juul Andersen: Multinational Performance Relationships and Industry Context.

2008-16 Larissa Rabbiosi: The Impact of Subsidiary Autonomy on MNE Knowledge Transfer: Resolving the Debate.

2008-17 Line Gry Knudsen \& Bo Bernhard Nielsen: Organizational and Individual Level Antecedents of Procedural Governance in Knowledge Sharing Alliances.

2008-18 Kirsten Foss \& Nicolai J. Foss: Understanding Opportunity Discovery and Sustainable Advantage: The Role of Transaction Costs and Property Rights.

2008-19 Teppo Felin \& Nicolai J. Foss: Social Reality, The Boundaries of Self-fulfilling Prophecy, and Economics.

2008-20 Yves Dos, Nicolai J. Foss \& José Santos: A Knowledge System Approach to the Multinational Company: Conceptual Grounding and Implications for Research

2008-21 Sabina Nielsen \& Bo Bernhard Nielsen: Why do Firms Employ foreigners on Their Top Management Teams? A Multi-Level Exploration of Individual and Firm Level Antecedents

2008-22 Nicolai J. Foss: Review of Anders Christian Hansen's “Uden for hovedstrømmen - Alternative strømninger i økonomisk teori"

2008-23 Nicolai J. Foss: Knowledge, Economic Organization, and Property Rights

2008-24 Sjoerd Beugelsdijk, Torben Pedersen \& Bent Petersen: Is There a Trend Towards Global Value Chain Specialization? - An Examination of Cross Border Sales of US Foreign Affiliates 